\title{
Depletion of transmembrane mucin 4 (Muc4) alters intestinal homeostasis in a genetically engineered mouse model of colorectal
}

\section{cancer}

\author{
Ramesh Pothuraju1 ${ }^{1}$, Priya Pai ${ }^{1,}{ }^{*}$, Sanjib Chaudhary ${ }^{1,}{ }^{*}$, Jawed A. Siddiqui ${ }^{1}$, Jesse L. Cox ${ }^{2}$, \\ Sukhwinder Kaur ${ }^{1}$, Satyanarayana Rachagani ${ }^{1}$, Hemant K. Roy ${ }^{3}$, Michael Bouvet ${ }^{4,5}$, \\ Surinder K. Batra ${ }^{1,6,7}$ \\ ${ }^{1}$ Department of Biochemistry and Molecular Biology, University of Nebraska Medical Center, Omaha, NE 68198, USA \\ ${ }^{2}$ Department of Pathology and Microbiology, University of Nebraska Medical Center, Omaha, NE 68198, USA \\ ${ }^{3}$ Department of Medicine, Baylor College of Medicine, Houston, TX 77030, USA \\ ${ }^{4}$ Division of Surgical Oncology, Department of Surgery, University of California San Diego, La Jolla, CA 92093, USA \\ ${ }^{5}$ VA San Diego Healthcare System, San Diego, CA 92161, USA \\ ${ }^{6}$ Fred and Pamela Buffett Cancer Center, University of Nebraska Medical Center, Omaha, NE 68198, USA \\ ${ }^{7}$ Eppley Institute for Research in Cancer and Allied Diseases, University of Nebraska Medical Center, Omaha, \\ NE 68198, USA \\ *Equal contribution
}

Correspondence to: Surinder K. Batra; email: sbatra@unmc.edu Keywords: mucin, MUC4, intestinal homeostasis, colorectal cancer Received: November 4, $2021 \quad$ Accepted: February 21, 2022

Published: March 7, 2022

Copyright: (c) 2022 Pothuraju et al. This is an open access article distributed under the terms of the Creative Commons Attribution License (CC BY 3.0), which permits unrestricted use, distribution, and reproduction in any medium, provided the original author and source are credited.

\section{ABSTRACT}

Mucins are components of the mucus layer overlying the intestinal epithelial cells, which maintains physiological homeostasis. Altered mucin expression is associated with disease progression. Expression of MUC4 decreases in colorectal cancer (CRC); however, its functional role and implications in the intestinal pathology in CRC are not studied well. Therefore, we generated a genetically engineered Muc4 knockout (Muc4 ${ }^{-/}$) CRC mouse model by crossing with Muc4 ${ }^{-/-}$and $A p c^{\text {flox/flox }}$ mice in the presence of colon-specific inducible Cre. We observed that deficiency of Muc4 results in an increased number of macroscopic tumors in the colon and rectal region and leads to poor survival. Further, the absence of Muc4 was associated with goblet cell dysfunction where the expression of intestinal homeostasis molecules (Muc2 and Fam3D) was downregulated. Next, we also observed that loss of Muc4 showed reduced thickness of mucus layer, leading to infiltration of bacteria, reduction in anti-microbial peptides, and upregulation of pro-inflammatory cytokines. Further, Apc gene mutation results in activation of the $W n t / \beta$-catenin signaling pathway that corroborated with an increased nuclear accumulation of $\beta$-catenin and activation of its target genes: cyclin D1 and c-Myc in Muc4 ${ }^{-/}$ mice was observed. We conclude that the presence of Muc4 is essential for intestinal homeostasis, reduces tumor burden, and improves overall survival.

\section{INTRODUCTION}

Colorectal cancer (CRC) occurs through a multi-step process (polyp-adenoma-carcinoma) in which several mutations are associated with disease progression $[1,2]$.
The most frequent mutations $(40-70 \%)$ occur in the adenomatous polyposis coli (APC) gene, a component of $\mathrm{Wnt} / \beta$-catenin signaling $[2,3] . \mathrm{CRC}$ is the third leading cause of cancer-related deaths in the United States of America and will account for approximately 
$1,49,500$ new cases and 52,980 deaths in 2021 [4]. As a result, studies have been conducted to understand CRC progression and various mouse models to identify potential treatments [5-7]. However, xenograft and chemically induced mouse models fail to recapitulate human CRC [7]. For instance, CRC induced by carcinogen affects several organs and also depends on route, dosage, and treatment duration [8]. Thus, genetically engineered mouse (GEM) models have great utility in studying CRC progression and can be used for evaluating pre-clinical therapeutic effectiveness. For instance, the sporadic CRC animal model has conditional mutations in the $A p c$ gene that develops tumors in the colon and rectal region by using the CreLox system.

Intestinal epithelial cells in the gut maintain homeostasis by preventing the entry of pathogens [9]. Such goblet epithelial cells produce several antimicrobial peptides and mucins, which are part of the mucus layer in the intestine [10]. Mucins are highmolecular-weight $O$-linked glycoproteins, and their altered expression or aberrant glycosylation is associated with many cancers $[11,12]$. For example, the transmembrane mucin MUC4 is overexpressed in pancreatic, ovarian, and breast cancers and is involved in metastasis [13-16]. In contrast, expression of MUC4 was significantly downregulated during adenoma and adenocarcinoma progression in CRC tissues as evident from human microarray analyses [17]. Initial identification of MUC4 expression was done in CRC tumors by Ogata and co-workers [18]. The study results showed that four CRC tumors had reduced expression of MUC4, and the rest of the tumors either had higher expression or expression similar to normal tissue [18]. In another study, hyperplastic polyps had a reduction in MUC4 expression, while tubular adenoma samples showed normal levels of MUC4 in the same study [19]. Similarly, non-mucinous tumors, which were $66 \%$, also had low to moderate levels of MUC4, while $34 \%$ of CRC patients had upregulation of MUC4 [20]. Thus, several studies suggested that MUC4 expression is lost or reduced in CRC [18, 21]. Despite loss or reduction of MUC4 expression in the majority $(75 \%)$ of CRC patient tumors, a small subset $(25 \%)$ of CRC patients had high expression of MUC4, particularly in stages I and II of the disease [22, 23]. Contrary, the pro-tumorigenic role of MUC4 has observed in chemical-induced colitis and CRC [24] models and hypothesized that the tumorigenic potential of MUC4 is due to truncated glycan epitopes present on it and altered binding affinity of MUC4 antibodies [25]. Thus, the role of MUC4 in homeostasis and disease pathology in the colon remains debatable. Therefore, to understand the functional significance of MUC4 in intestinal homeostasis and CRC progression, we developed a GEM model by crossing mice carrying a conditional mutation of $A p c$ gene with colon-specific caudal type homeobox transcription factor $2(\mathrm{Cdx} 2)$-Cre fused with estrogen receptor.

\section{RESULTS}

\section{Low MUC4 expression is associated with poor survival in CRC patients}

Our analysis showed a significant $(p<0.05)$ downregulation of MUC4 expression in CRC patients compared to normal individuals by using The Cancer Genome Atlas (TCGA-COAD) database (containing 286 colon cancer and 41 normal samples) (Figure 1A). In addition, we also analyzed MUC4 expression in two datasets (GEO accession: GSE17536, $p<0.01$ and GSE17537, $p<0.01)$ and observed that patients with high MUC4 expression showed a significant improvement in overall and disease-free survival (Figure 1B), suggesting a protective role of MUC4 in CRC.

\section{Muc4 deletion drives colorectal tumors with high- grade dysplasia}

To understand the role of transmembrane mucin Muc4 in CRC initiation and progression, we generated $\mathrm{Apc}^{-/}$ ; Muc4 $^{-1-} ; \mathrm{Cdx} 2 \mathrm{P}-$ creERT $^{2}$ (referred to AMC) and its contemporary littermate control $\mathrm{Apc}^{-1-} ; \mathrm{Cdx} 2 \mathrm{P}-\mathrm{creERT}^{2}$ (AC) mice (Figure 1C). After confirming genotype, crerecombination was carried out by administering tamoxifen intraperitoneally (Figure 1D), and mice from both groups were euthanized based on the incidence of symptoms (rectal bleeding, kyphosis, and lethargy) (Figure 2A). AMC animals displayed an increased number of macroscopic polyps in the large intestine (Figure 2B, 2C). In addition, histological examination of colorectal tissue of AMC mice revealed that all adenomas were high-grade dysplasia without reaching muscularis layer of the colon (Figure 2D).

\section{Loss of Muc4 shows goblet cell dysfunction}

Next, we characterized goblet cell function in all animal groups by staining Swiss rolled colon tissues with Alcian blue (stains acidic mucins) and Periodic acid-Schiff (PAS, neutral mucins). We observed that in both AMC and $\mathrm{AC}$ mice, there was a complete absence or loss of staining in the goblet cells of colon adenoma (Figure 2E), suggesting that disruption of goblet cell function alters the mucin production. There was an increase in the crypt length of AMC mice associated with strong Ki67-positive staining in the proliferating epithelial cells in the colon with a disorganized pattern. In contrast, normal animals showed Ki67 staining mostly restricted at the bottom of the crypt, absent in the epithelial cells towards the top of the crypt (Figure 3A). 

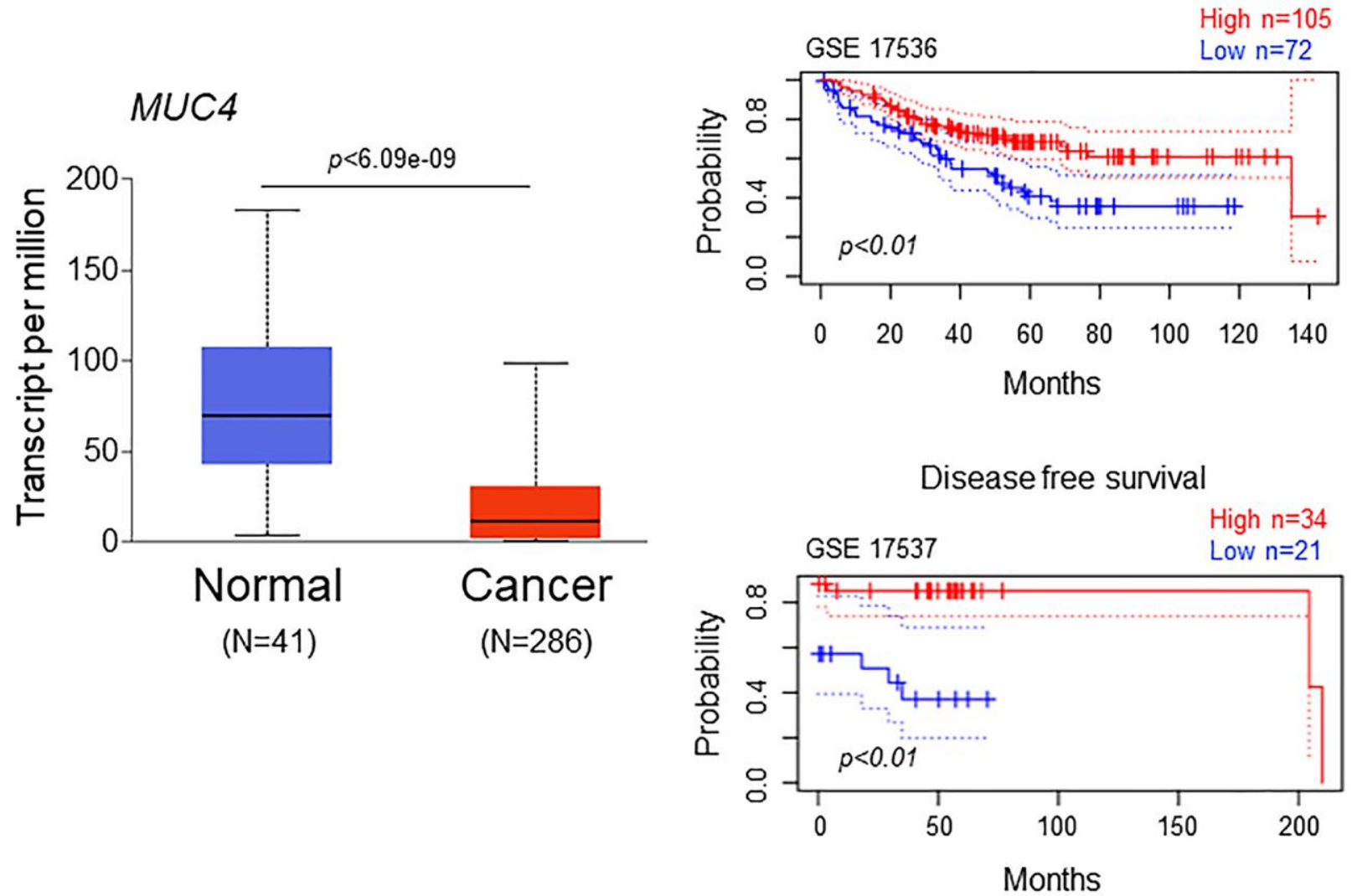

C

D
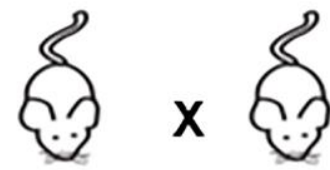

$\mathrm{Apc}^{\mathrm{CKO}}$ Muc4-1-

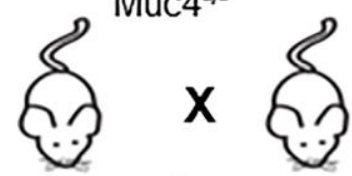

Apc $^{+/-}$;Muc4 ${ }^{-/-}$Cdx2P-CreER ${ }^{\text {T2 }}$

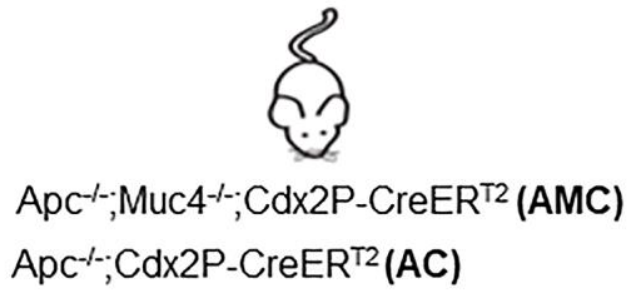

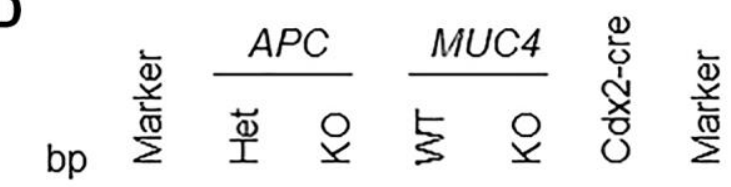

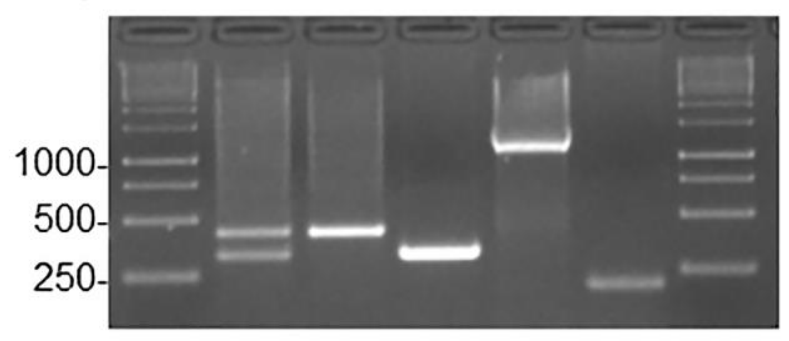

Tamoxifen

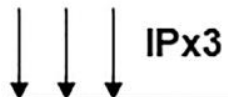

Days $-3-2-1$

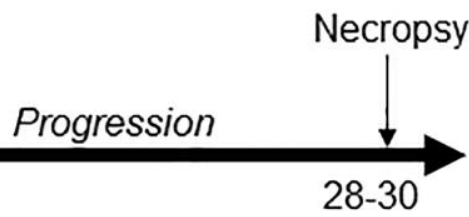

Figure 1. Low MUC4 expression is associated with poor survival in CRC patients. (A) A significant $(p<6.09 \mathrm{e}-09)$ upregulation of MUC4 in normal $(\mathrm{N}=41)$ and downregulation in CRC patients $(\mathrm{N}=286)$ was analyzed in the TCGA-COAD dataset. (B) Increased expression of MUC4 is associated with better overall and disease-free survival in CRC patients' data sets (GSE 17536 and GSE 17537). (C) Breeding strategy for the generation of a genetically engineered mouse model for Muc4\% by crossing with Apc flox/flox mice. First-generation of double knockout

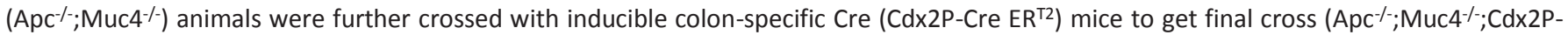
$\mathrm{CreER}^{\mathrm{T} 2}, \mathrm{AMC}$ ) and its littermate controls (Apc $\left.{ }^{-1-} ; \mathrm{Cdx} 2 \mathrm{P}-\mathrm{CreER}^{\mathrm{T} 2}, \mathrm{AC}\right)$. (D) PCR products of $A p c$ and Muc4 and Cdx2-cre animals of genomic DNA. Below, induction of Cre recombination by tamoxifen administration ( $75 \mathrm{mg} / \mathrm{kg}$ body weight, 3x) via intraperitoneally. 
A

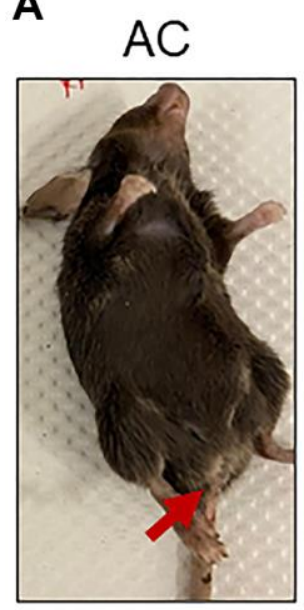

B

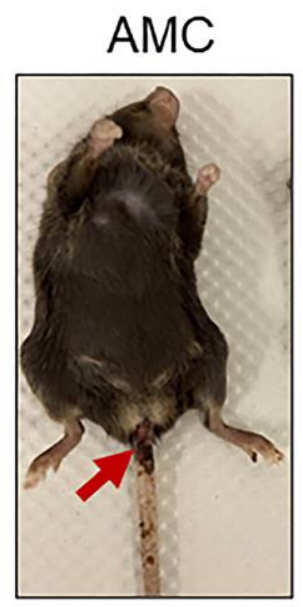

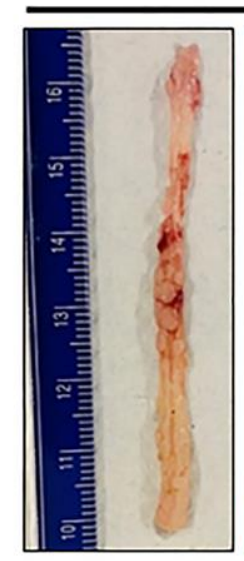

AC

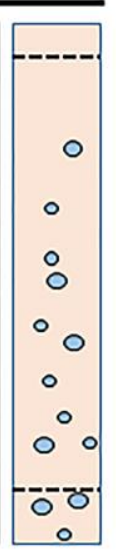

AMC

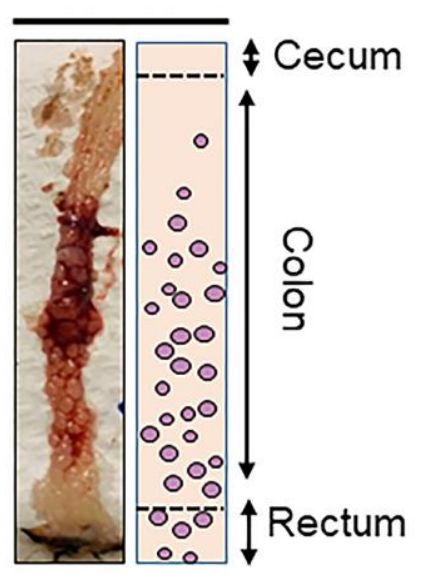

C

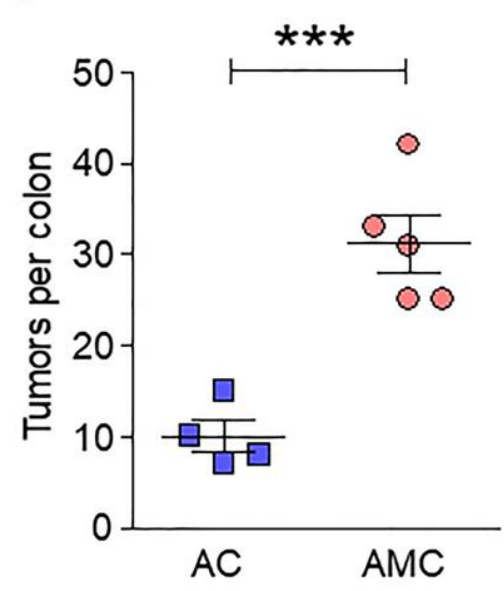

D

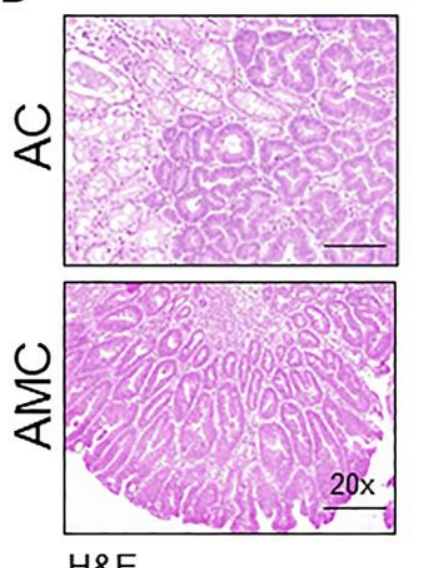

H\&E

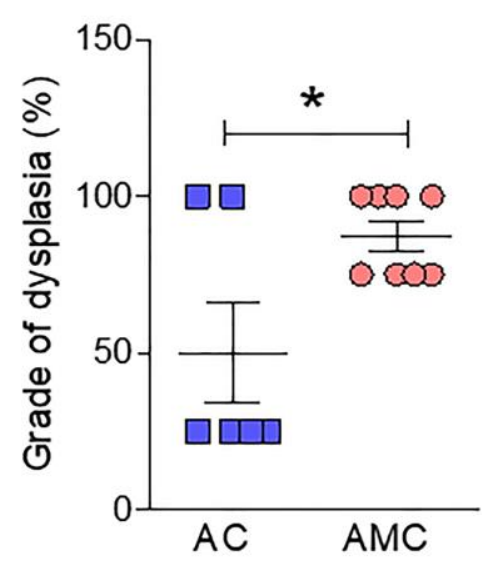

E
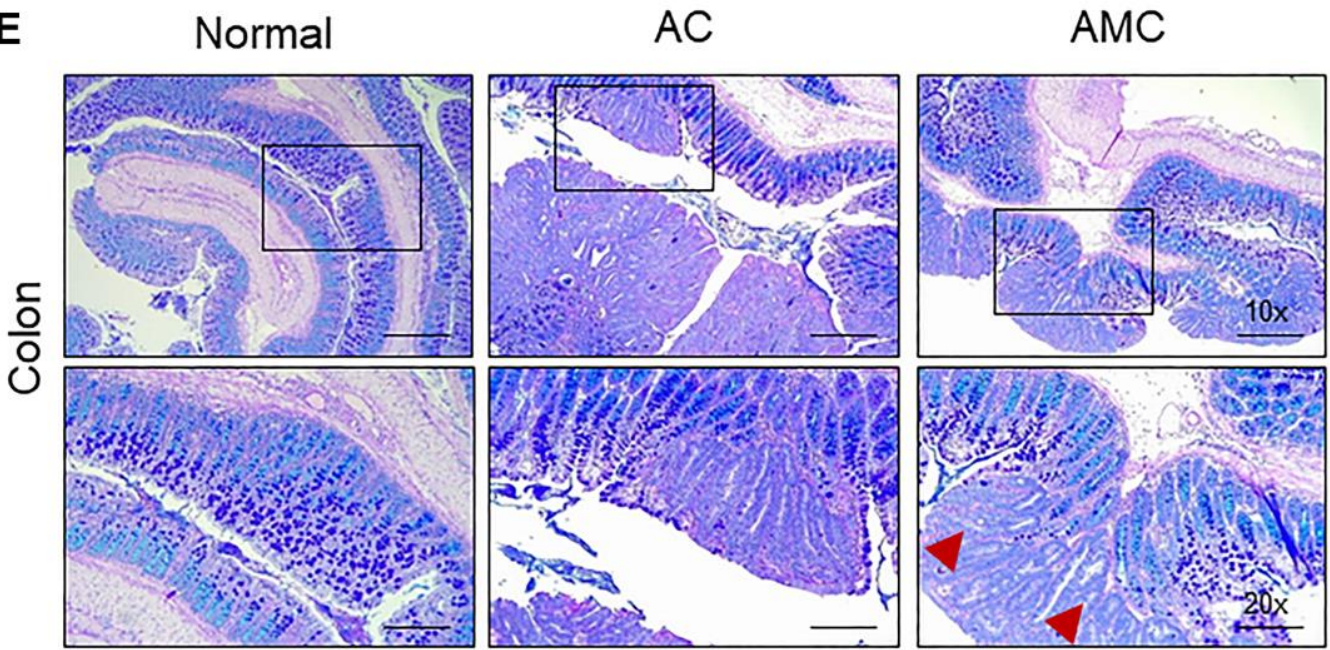

Alcian blue/PAS

Figure 2. Muc4 deletion drives colorectal tumors with high-grade dysplasia and goblet cell dysfunction. (A) Representative images of $A C$ and $A M C$ animals had typical rectal bleeding. (B, C) Muc4\% mice in the AMC group showed an increase in the number of macroscopic polyps in the colon and rectal region. $n=4-5$ per group. (D) H\&E staining of AMC animals had a higher grade of dysplasia. $n=6-8$ per group. (E) Representative images of double staining of Alcian blue and PAS. $n=6$ (AC and AMC) and $n=3$ for normal group. Red arrowhead indicates loss of mucins expression in the goblet cells in AMC mice. ${ }^{*} p<0.05, * * * p<0.001$. 
A

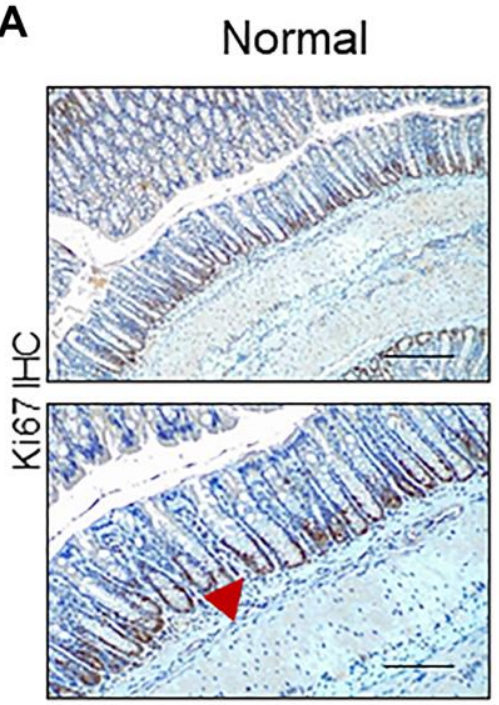

B

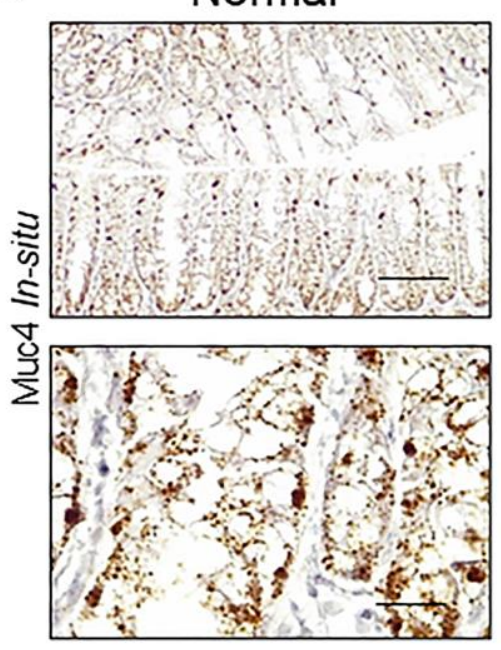

C

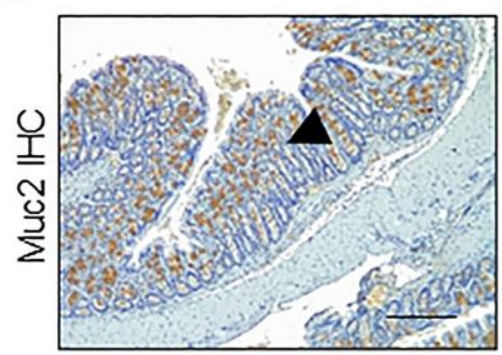

AC
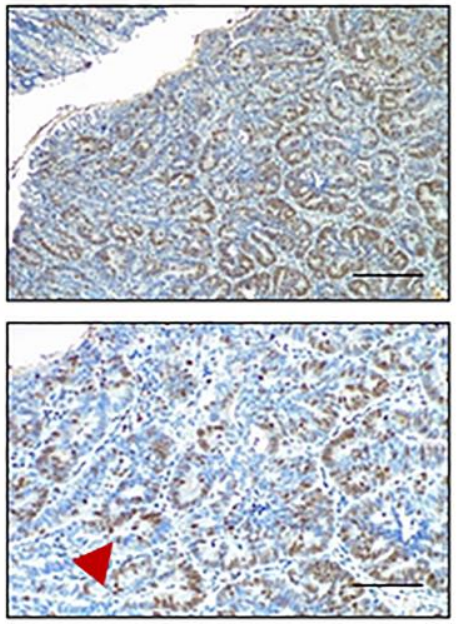

AMC
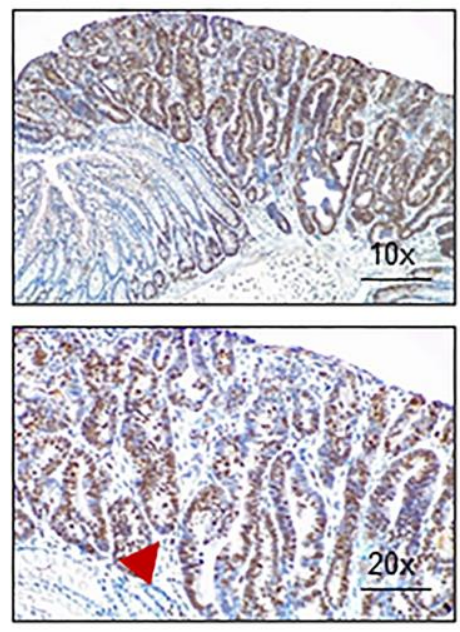

AC
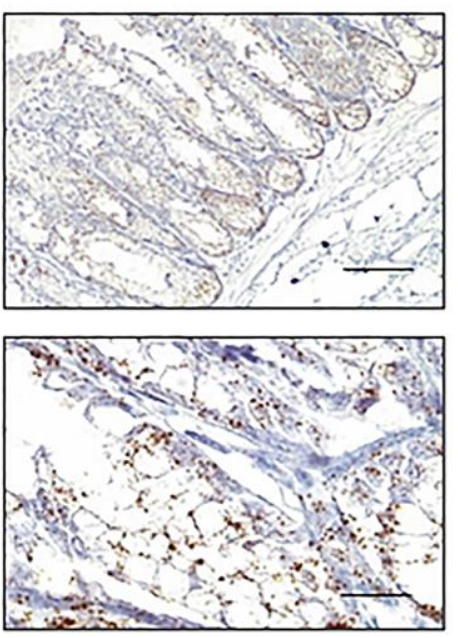

AC

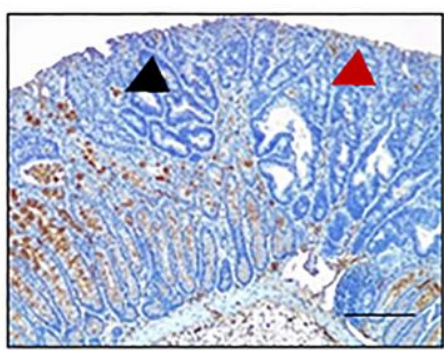

AMC
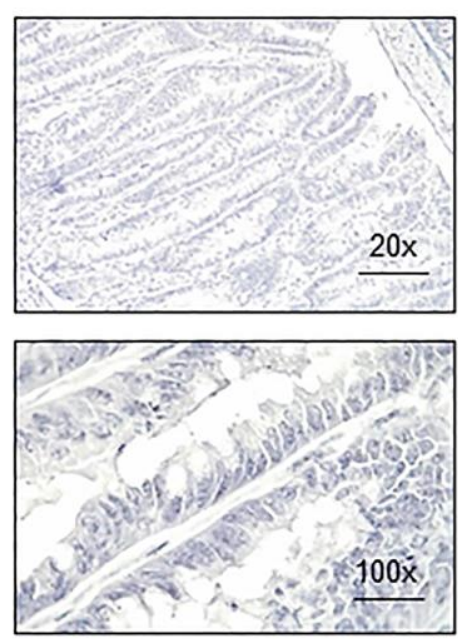

AMC

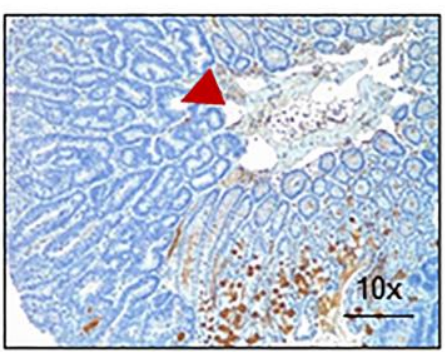

Figure 3. Absence of Muc4 alters other mucins expression. (A) Immunohistochemistry staining of Ki67 in the colon of normal, AC, and AMC mice. Red arrowhead indicates Ki67 staining restricts to crypts in normal animals, whereas AMC mice showed higher cell proliferation (more Ki-67 staining), which might be attributable to colonic crypt hyperplasia. (B) Staining of Muc4 was observed in normal, AC mice, whereas the complete absence of Muc4 expression in AMC animals was performed by in-situ hybridization. (C) Immunohistochemistry staining of Muc2 (Black arrowhead: positive staining and Red arrowhead: absence of staining in the tumors). $n=6$ ( $A C$ and $A M C)$ and $n=3$ for normal group. 


\section{Absence of Muc4 alters other mucins expression}

The expression of secreted mucin Muc2, which is a major component of the mucus layer, and the membrane-bound mucin Muc13, Muc16, and another secretory mucin Muc5ac (has a role in tumorigenesis, metastasis, and drug resistance) was examined. The complete loss or deletion of Muc4 in AMC mice (Figure 3B) was associated with a significant loss of Muc2 in the colon adenoma compared to normal mice (Figure 3C). However, the expression of other mucin Muc13 was up-regulated, while no changes in Muc16 and Muc5ac at transcript levels in AMC compared to AC mice. (Supplementary Figure 1A).

\section{Muc4 deletion results in defective mucus barrier function and reduced intestinal homeostatic molecules}

Like Muc2, the gut secreted protein Fam3d is essential for colon homeostasis [26]. Human FAM3 consists of four gene families: FAM3A, FAM3B, FAM3C, and FAM3D [26]. Among all FAM3 family members, the expression of $F A M 3 D$ is significantly downregulated in human $\mathrm{CRC}$ patients compared to normal individuals (Figure 4A and Supplementary Figure 1B). Therefore, we examined the expression of Fam3d and observed that Fam3d was expressed in Muc2 positive goblet cells in the normal mice, while its expression was greatly diminished or lost in the adenoma region of AMC mice (Figure 4B), suggesting that loss of both Muc2 and Fam3d reduces intestinal mucus layer thickness in AMC animals. Both Muc2 and Fam3d have been involved in preventing the entry of bacteria maintaining the colon homeostasis, as evidenced in several studies [26, 27]. Therefore, we analyzed the colon tissue sections for bacterial invasion by FISH using a general 16S rRNA probe (EUB338). Compared to the AC, AMC mice colon had reduced mucus layer thickness, resulting in more bacteria infiltration in the colonic epithelial tissues (Figure 4C). Further studies are necessary to understand the various individual bacterial populations in the AMC model to determine the role of Muc4 in altering the gut microbiota. Next, we determined the expression of intestinal homeostatic antimicrobial peptides (Reg3b, $\operatorname{Reg} 3 \gamma$, and Saa3) in colon of AMC and AC mice. Interestingly, we observed that the absence of Muc4 resulted in significant down regulation of these antimicrobial peptides at mRNA levels (Figure 4D). The absence of Muc4 in AMC mice resulted in severe bleeding in the large intestine (Figure 2A, 2B). To examine whether the bleeding recruits any cytokines and inflammatory cells, we analyzed the expression of proinflammatory cytokines such as Tnfa, IL-6, Cxcl2, Ccl2, Cxcll and IL-1 and observed that AMC animals showed up regulation of cytokines (Supplementary
Figure 2A) whereas, no difference in the expression of $\mathrm{F} 4 / 80$ and $\mathrm{CD}^{+} \mathrm{T}$ cells staining in AMC and $\mathrm{AC}$ animals (Supplementary Figure 2B).

\section{Muc4 deletion results in up-regulation of $\beta$-catenin signaling}

Wnt/ $\beta$-catenin signaling plays an essential role in CRC progression. Around $90 \%$ of human CRC tumors contain mutations in the Wnt pathway, while $50-80 \%$ of CRC patients have an accumulation of $\beta$-catenin in the nucleus [28]. Therefore, we analyzed the expression of $\beta$-catenin in the nucleus by immunohistochemistry in both AMC and AC mice. Interestingly, $\mathrm{AMC}$ animals showed a significantly $(p<0.02)$ higher nuclear accumulation of $\beta$-catenin compared to AC mice (Figure 5A, 5B). Similarly, we also identified a significant $(p<2.404 \mathrm{e}-4)$ negative correlation between MUC4 and $\beta$-catenin in CRC patient dataset (Figure 5C). Further, mRNA and western blot analysis confirmed higher expression of $\beta$-catenin and its target molecules such as cyclin-D1, c-Myc, and CD44 in AMC mice (Supplementary Figure $3 \mathrm{~A}$ and Figure 5D).

Next, we assessed the relationship between the MUC4 and $\beta$-catenin in the human CRC cell line. First, we screened a panel of CRC cell lines for MUC4 expression (Figure 6A) and other mucins such as MUC5AC, MUC1, MUC13 (Supplementary Figure 3B). The MUC4 expressing LS-180 and HCT-8 CRC cell lines were selected and then performed stable knockdown of MUC4 in both CRC cell lines (Figure 6B). Knockdown (KD) of MUC4 increased the expression of $\beta$-catenin, cyclin-D1, and CD44 at the transcript level in LS-180 and HCT-8 cells (Supplementary Figure 3C). Our cellular fractionation study also revealed that the MUC4-KD in the LS-180 cell line resulted in increased localization of $\beta$-catenin in the nucleus compared to a cytosolic fraction (Figure 6C). These data suggest that the presence of Muc4 prevents nuclear translocation of $\beta$-catenin in both in vitro and in vivo studies; however, further studies are needed to prove the molecular mechanism by which Muc4 modulates the $\mathrm{Wnt} / \beta$-catenin signaling pathway(s).

\section{Additional kras mutation aggravates Apc tumors and reduces survival}

Early CRC tumors typically possess $30-50 \%$ activation mutations in the Kras (45\%) gene along with Apc mutations [3]. Hence, to understand the significance of Kras mutations in CRC, we crossed LSL-Kras mice [B6.129-Krastm4Tyj (01XJ6) from NCI Mouse Models of Human Cancers Consortium, Frederick, MD, USA] [29] with $\mathrm{AMC}$ and generated $\mathrm{Apc}^{-/-} ; \mathrm{Kras}^{\mathrm{Gl2D} /+} ; \mathrm{Muc}^{-/-}$; 
$\mathrm{Cdx} 2 \mathrm{P}$-creERT ${ }^{2}$ (referred as AKMC) and its littermate controls $\mathrm{Apc}^{-/} ; \quad \mathrm{Kras}^{\mathrm{G} 12 \mathrm{D} /++} ; \mathrm{Cdx} 2 \mathrm{P}-$ creERT $^{2} \quad(\mathrm{AKC})$ (Figure 7A). The activation of cre-recombination was carried out as described in Figure 1D. Interestingly, additional kras mutation in AKMC mice did not observe any macroscopic tumors in the colon (Figure 7B). However, tumor histology of the colon reveals both AKMC and AKC animals had low-grade dysplastic

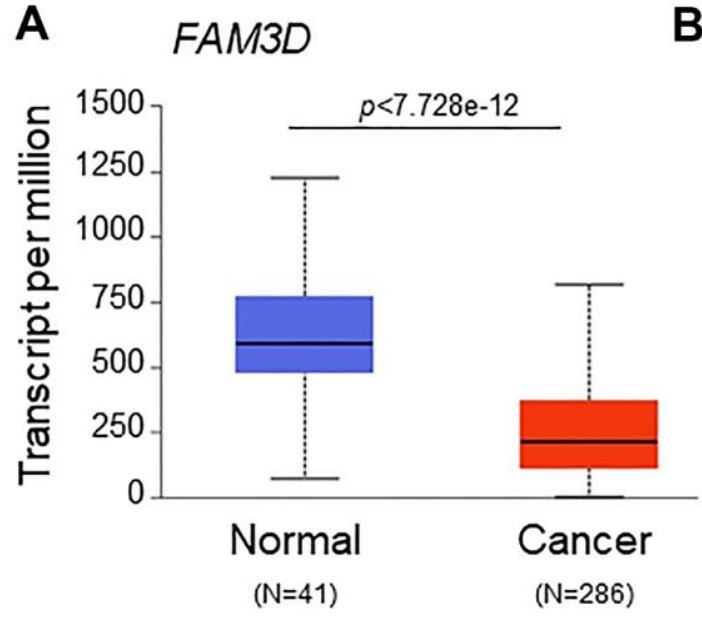

C

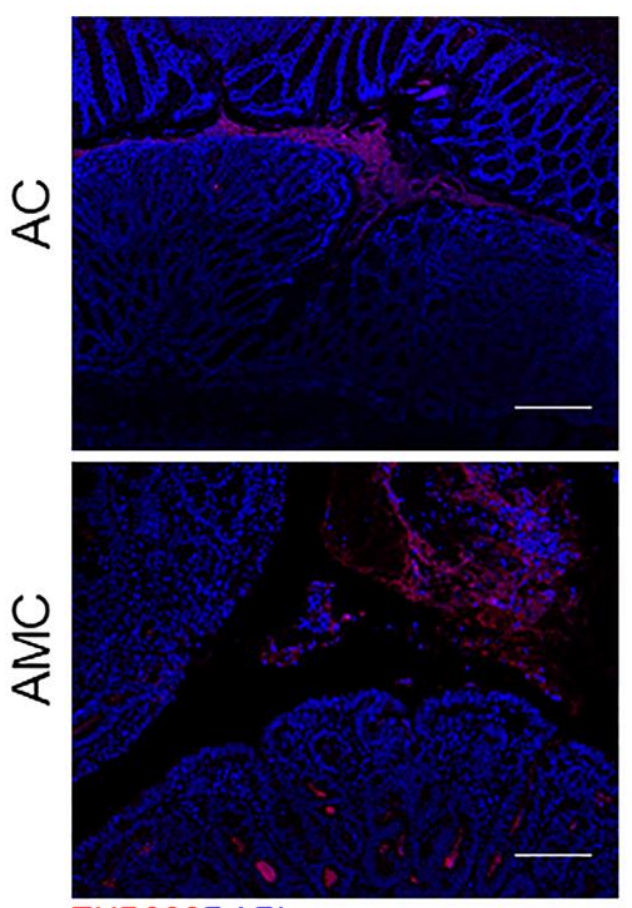

EUB388DAPI
B Normal

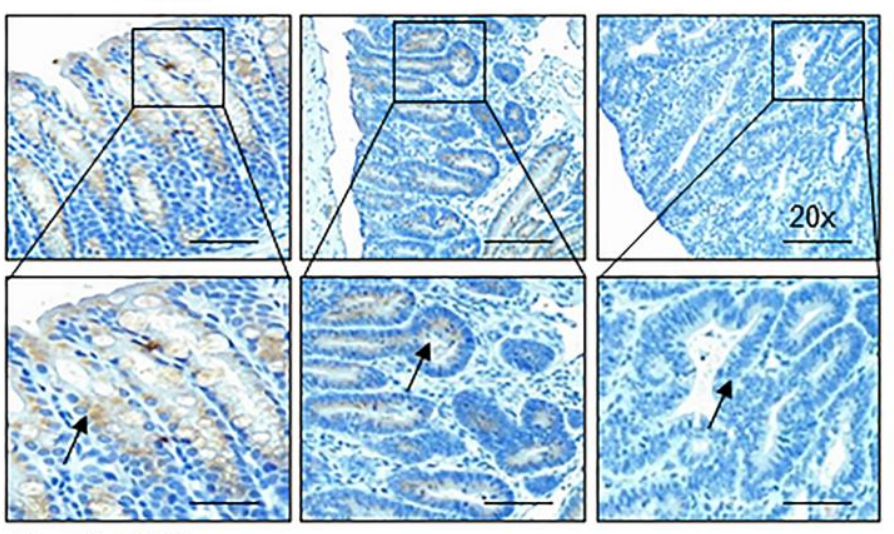

Fam3d IHC
D

\section{Antimicrobial peptides}
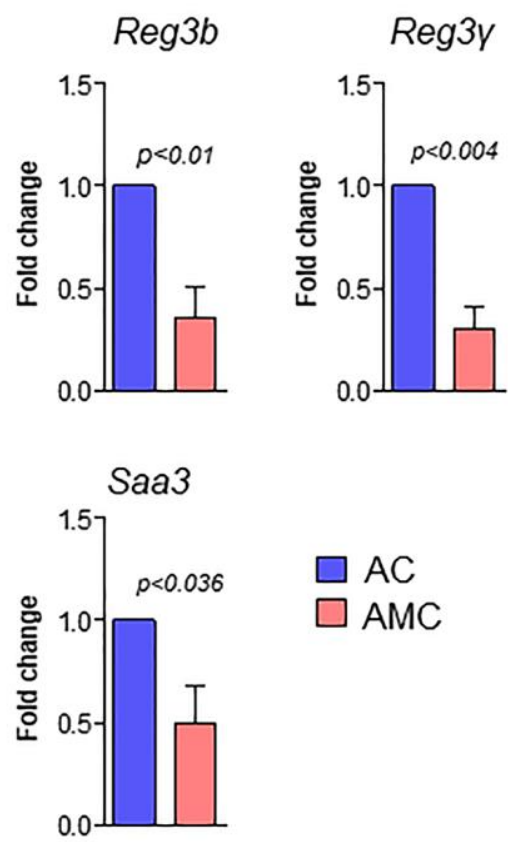

Figure 4. Muc4 deletion results in defective mucus barrier function and reduced intestinal homeostasis molecules. (A) TCGACOAD dataset showed down-regulation of FAM3D in CRC patients $(N=286)$ compared with healthy controls ( $N=41)$. (B) Immunohistochemistry analysis of Fam3d expression in the colon of normal, AC, and AMC mice. $n=6$ ( $A C$ and $A M C$ ) and $n=3$ for normal group. (C) Representative images of immunofluorescent staining of bacteria (red color) done by fluorescence in-situ hybridization using EUB338-Cy3 probe. $n=3$ per group. (D) mRNA expression levels of antimicrobial peptides (Reg3b, Reg3 $\gamma$, and Saa3) in the colons of AC and AMC mice were measured by real-time PCR. $n=3-4$ per group. 
A

Normal

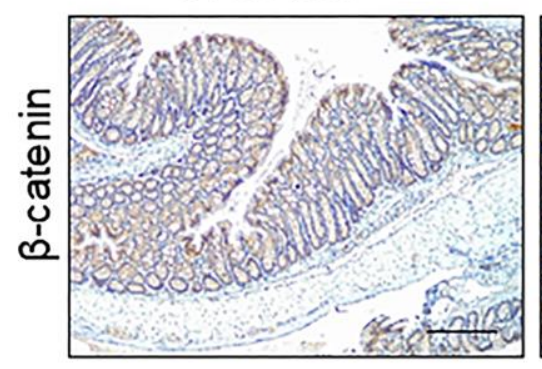

B

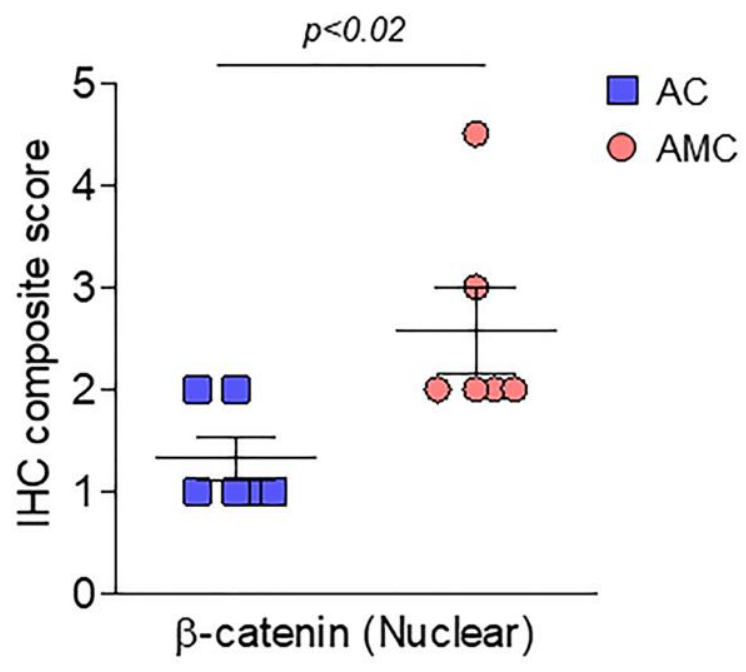

AC

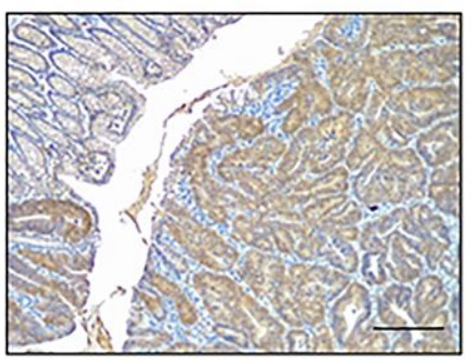

AMC

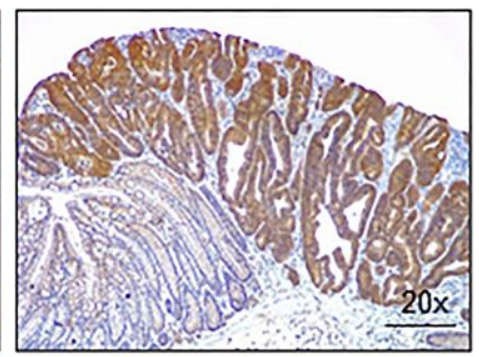

C

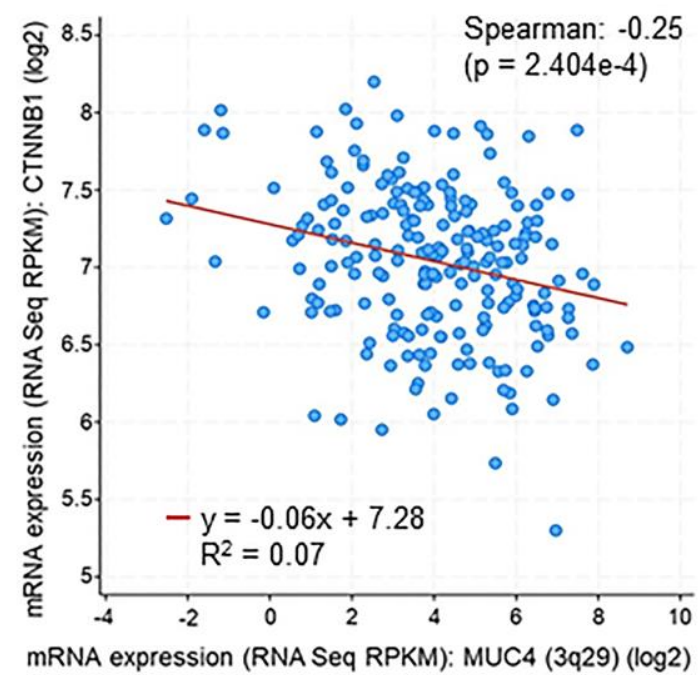

D
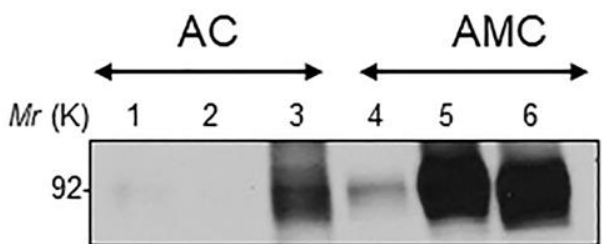

Active $\beta$-catenin (low)

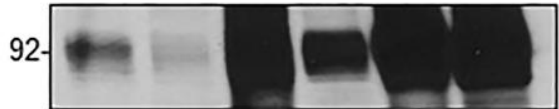

Active $\beta$-catenin (high)

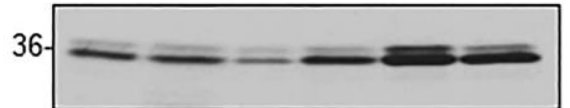

Cyclin-D1

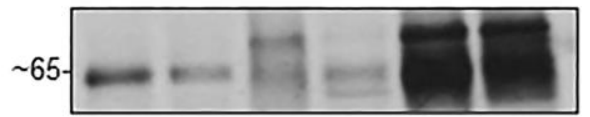

c-Myc

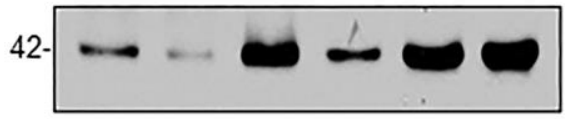

$\beta$-actin

Figure 5. Muc4 deletion results in up-regulation of $\beta$-catenin signaling. (A) Immunohistochemical analysis of $\beta$-catenin in normal, $A C$ and $A M C$ animals. $n=6$ (AC and $A M C$ ) and $n=3$ for normal group. (B) IHC composite score of nuclear $\beta$-catenin staining in AC and AMIC mice (C) MUC4 and CTNNB1 ( $\beta$-catenin) correlated negatively in the TCGA-COAD dataset. (D) Immunoblot of active $\beta$-catenin and its target genes: cyclin-D1 and c-Myc expression in AC and AMC animals. $n=3$ per group. 
(Figure 7C). Further, these animals had a shorter life span than $\mathrm{AMC}$ and $\mathrm{AC}$ mice (Figure 7D).

\section{DISCUSSION}

Transmembrane mucin MUC4 is differentially expressed in various cancers. In early gastric cancer, expression of MUC4 was associated with lymphatic invasion, lymph node metastasis and predicted poor prognostic factors [30]. Further, the importance of MUC4 expression was identified in invasive ductal carcinoma (ICD) of the pancreas. The study concluded that in surgical resected IDC, MUC4 could serve as a valuable indicator to predict the outcome of patients [31]. Mechanistic studies suggest that the presence of MUC4 mediates pancreatic cancer cell invasion and metastasis by stabilizing fibroblast growth factor receptor 1 [32] and oncogenic signaling via interaction with HER3 [33]. Contrary, MUC4 has a tumor suppressor role in non-small-cell lung cancer by altering p53 expression [34]. Therefore, the present study focused on understanding the role of MUC4 in CRC progression and alteration of intestinal barrier function by developing a GEM model having an Apc mutation with or without Muc4 using colon-specific Cdx2-Cre mice. Previously, we showed that MUC4 expression is significantly downregulated in human CRC patient tissues compared to normal individuals [17]. Similarly, the TCGA-COAD database also showed that lowered expression of MUC4 in normal
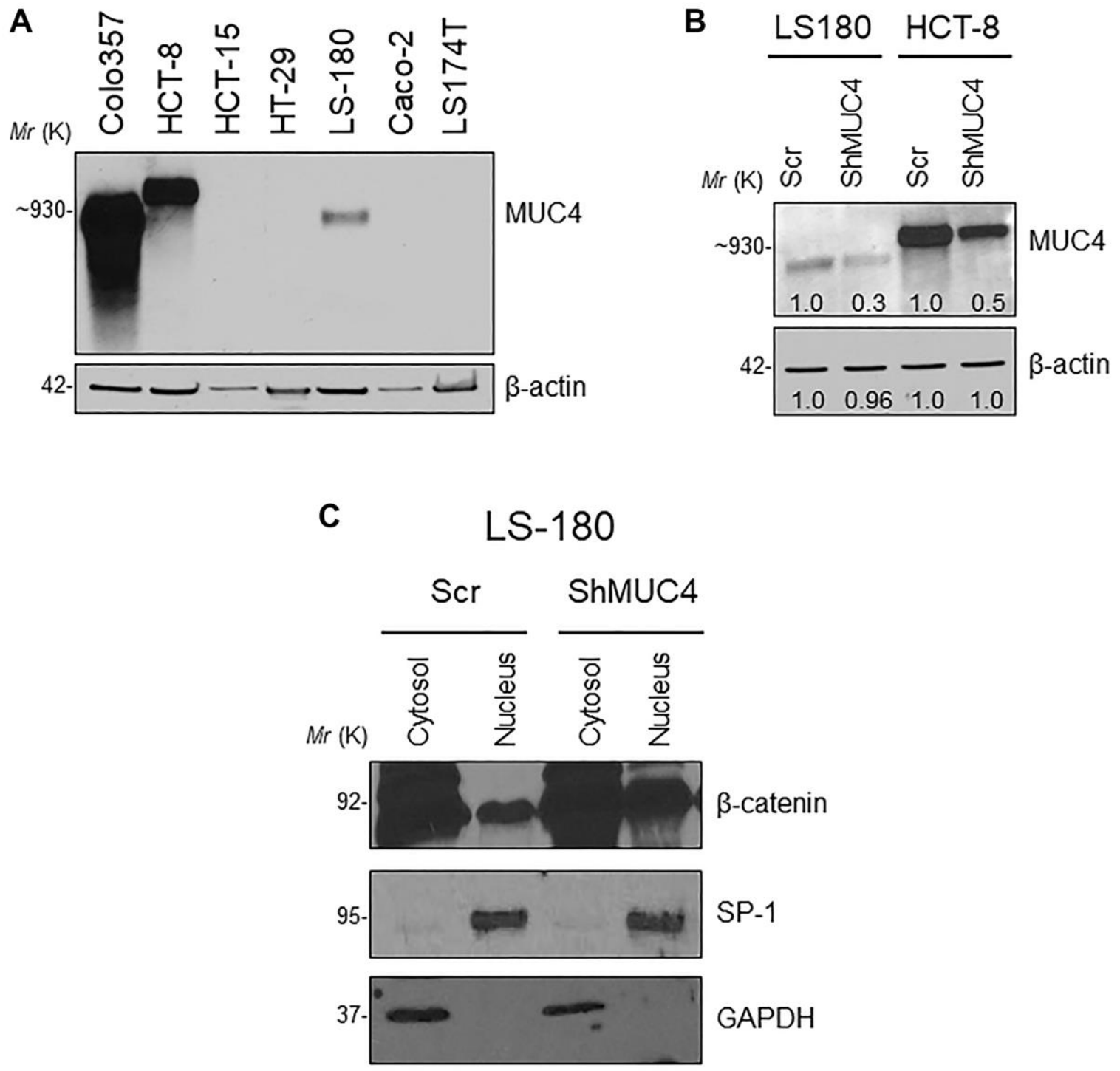

Figure 6. Knockdown (KD) of MUC4 in CRC cell lines mediates $\boldsymbol{\beta}$-catenin signaling. (A) A panel of CRC cell lines was used and screened for MUC4 expression (Colo357 pancreatic cancer cell line used as a positive control). (B) Stable KD of MUC4 in both LS-180 and HCT8 CRC cell lines. (C) Expression of nuclear $\beta$-catenin levels in a sub-cellular fraction of CRC cell line done by western blot. 
A

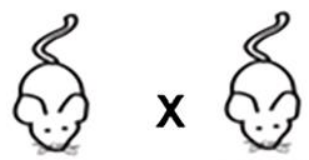

$\mathrm{Apc}^{-/-}, \mathrm{Muc}^{-/-}$<smiles>[As]c1ccccc1</smiles>

$\mathrm{Apc}^{-/-} ; \mathrm{Muc4}^{-/-} ; \mathrm{Kras}^{\mathrm{G} 12 \mathrm{D} /+} \mathrm{Cdx} 2 \mathrm{P}-\mathrm{CreER}{ }^{\mathrm{T} 2}$<smiles>c1ccc(-c2ccccc2)cc1</smiles>

$\mathrm{Apc}^{-1-;} \mathrm{Muc4}^{-1-;} ; \mathrm{Kras}^{\mathrm{G} 12 \mathrm{D} /++} ; \mathrm{Cdx} 2 \mathrm{P}-\mathrm{CreER} \mathrm{R}^{\mathrm{T} 2}$ (AKMC)

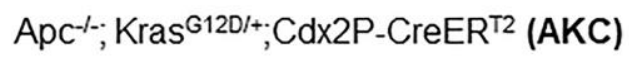

C

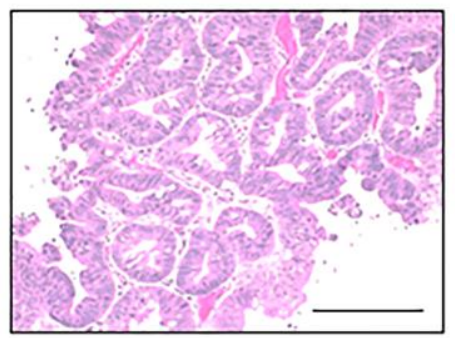

H\&E
B

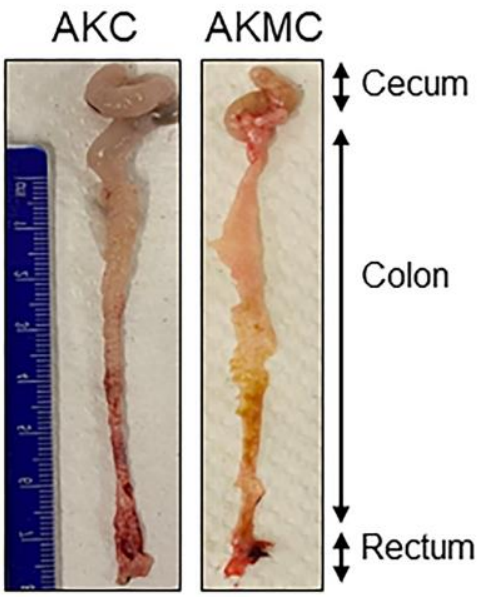

D

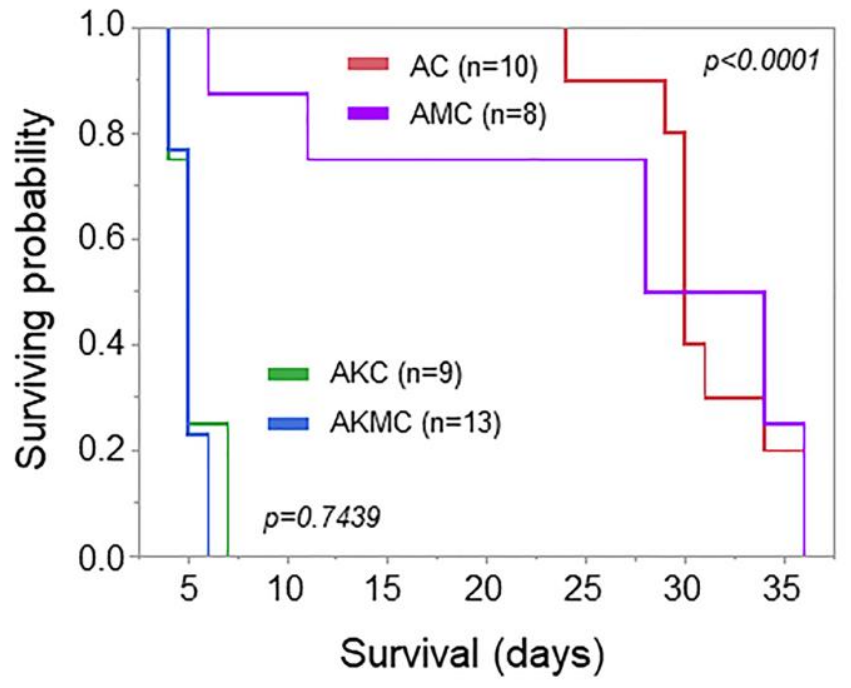

Figure 7. Additional Kras mutation aggravates Apc tumors and reduces survival. (A) Breeding strategy for generation of genetically

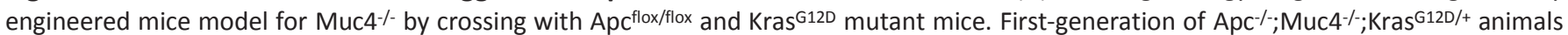

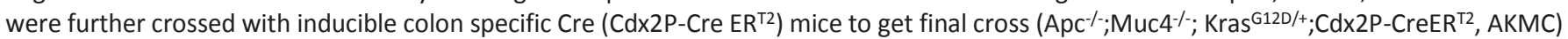
and its littermate controls (Apc ${ }^{-/ ;} ; \mathrm{Kras}^{\mathrm{G} 12 \mathrm{D} /+} ; \mathrm{Cdx} 2 \mathrm{P}-\mathrm{CreER}^{\mathrm{T}}$, AKC). (B) Representative images of the colon in AKC and AKMC animals. (C) H\&E images showed a grade of dysplasia in AKC and AKMC mice. $n=3$ for AKC and $n=6$ for AKMC group. (D) Overall survival curves of different mouse models used in the present study. ns = non-significant. 
individuals is associated with poor survival. Therefore, we investigated the potential role of Muc4 in CRC by using a GEM model with an Apc mutational background.

In our study, loss of Muc4 in AMC mice resulted in severe rectal bleeding with more adenomas in the colon and rectal regions. We speculated that bleeding in AMC animals might be due to the infiltration of immune cells and the release of pro-inflammatory cytokines. Interestingly, we noticed high expression (without significant level) of inflammatory cytokines whereas infiltration of $\mathrm{F} 4 / 80^{+}$macrophages and $\mathrm{CD}^{+} \mathrm{T}$ cells was higher in both AMC and AC compared to normal animals, suggesting a low level of inflammation in the mice colons.

The intestinal mucus layer comprises different mucins and is a key barrier in the colon to prevent bacterial invasion into the colon epithelium [3, 35]. Our results demonstrate that combined loss of Apc and Muc4 in AMC animals impaired mucosal barrier function with reduced expression of mucins (confirmed by Alcian/PAS staining), especially Muc2. Secretory mucin Muc2 is abundant mucin in the intestinal mucus layer [27]. It is a large glycoprotein having $O$-linked glycans attached on its domains. The colon has two dramatic mucus layers: the outer (loosely attached) and the inner layer (tightly attached), which is devoid of bacteria [3, 36, 37]. The terminal sulfate and sialic acids on mucins are degraded by the microbial enzymes (sialidases and glycosulfatases) [38-40], resulting in the loss or reduction of mucin expression in the outer mucus layer of the large intestine to alter gut flora. In a study, Muc2 ${ }^{--}$mice displayed infiltration of bacteria into crypts due to intestinal barrier damage, which triggered an inflammation-mediated CRC [27], and its absence promotes CRC progression [41]. Thus, lack or loss of Muc2 expression in AMC mice was associated with a reduction in the mucus layer thickness and downregulation of antimicrobial peptides, which was associated with gut dysbiosis that resulted in infiltration of bacteria into the epithelium. Based on our findings, we conclude that the deletion of Muc4 may contribute to goblet cell dysfunction, resulting in alteration of mucin expression (Muc2), leading to dysbiosis. Along with MUC2, MUC13, MUC16, and MUC5AC have been implied in CRC progression, metastasis, and chemoresistance [42-44]. In the present study, we observed that Muc13 was upregulated in the absence of Muc4, suggesting its tumor-promoting role in CRC. Further studies on Muc4 and other mucus components responsible for the mucus layer formation and maintaining intestinal homeostasis are needed.

Like Muc2, a gut secreted protein, FAM3D is also essential for maintaining colon homeostasis [26].
Genetic deletion of Fam3D ${ }^{-/}$in mice showed decreased intestinal integrity, hyper-proliferation, and reduction in anti-microbial peptide production. Further, the absence of Fam3D was associated with altered gut microbiota [26]. Interestingly in our AMC animals, we observed that less expression of Fam3D compared to AC mice, which was corroborated in a human CRC patients' dataset. Thus, we concluded that the decreased expression of Fam3D leads to more bacterial invasion into the intestinal epithelial cells of AMC animals. However, the relationship of mucins (Muc4 \& Muc2) and Fam3D and their significance in facilitating microbiota composition need to be addressed in future studies.

Dysregulation of $\mathrm{Wnt} / \beta$-catenin signaling is involved in several types of cancer, including CRC, to promote cell proliferation, invasion, and metastasis [45-47]. Mutation in the $A P C$ gene stabilizes cytoplasmic unphosphorylated $\beta$-catenin to enter the nucleus. It binds and activates transcription factors ( $\mathrm{T}$ cell factor or lymphoid enhancer factors) to transcribe its target genes for CRC progression $[44,48,49]$. Previously, we have shown that Muc4 is negatively regulated through the $\mathrm{Wnt} / \beta$-catenin signaling in CRC cell lines [50]. In the present study, we observed a higher nuclear accumulation of $\beta$-catenin in AMC mice colon tissues, resulting in upregulation of its target genes cyclin-D1 and c-Myc, which are essential for the proliferation of colonic epithelial cells. Further, to understand the relationship between Muc4 and $\beta$ catenin, we performed a stable knockdown of MUC4 in the human CRC cell line. Decreased expression of MUC4 results in more expression of $\beta$-catenin in the nuclear fraction. In contrast, Muc13 protects $\beta$-catenin degradation from glycogen synthase kinase $3 \beta$ there by inducing nuclear translocation of $\beta$-catenin and activating the $\mathrm{Wnt} / \beta$-catenin signaling pathway in a dextran sodium sulfate-induced CRC mice model [44]. Other studies have shown MUC1, and MUC4 have been to promote nuclear localization of $\beta$-catenin in gastrointestinal and colorectal cancers $[44,50,51]$. The presence of Muc4 might be associated with the $\beta$-catenin destruction complex components, which results inhibit the nuclear accumulation. However, the mechanism(s) by which Muc4 tethers the $\beta$-catenin in the cytosol needs to be studied.

Over the past decades, GEM models for CRC have been developed [49, 52-55]. The most used CRC mice model is $\mathrm{Apc}^{\mathrm{Min} /+}$ mice; however, this model develops around 20-30 tumors mostly in the small intestine rather than the colon $[56,57]$. Currently, several CRC mice models have been developed, which closely mimic human $\mathrm{CRC}$, and these models form tumors mainly in the large intestine and occasionally in the small intestine $[6,7$, 58, 59]. Here, we used Apc ${ }^{\text {flox/flox }}$ mice and observed 
tumors mostly in the large intestine; however, germline Apc mutations do not promote spontaneous Kras mutations $[6,60]$. Around $50 \%$ of CRC patients have activating mutations in Kras [61]. Therefore, we introduced the activated Kras gene in our AMC and AC mice models and investigated whether the incorporated Kras gene would exacerbate invasive tumor progression and metastasis. We did not observe any macroscopic tumors in both AKMC and AKC mice, though histological analysis revealed more dysplasia without invasive lesions and no metastasis, which is corroborated with other studies [5]. Moreover, these mice had lower survival due to kyphosis, weight loss, rectal prolapse, and bleeding, indicating early euthanasia compared to AMC and AC mouse models, resultant in Kras activation [62]. Contrasting evidence with the addition of the Kras allele is reported to promote invasive tumors and metastasis [6, 63-65]. However, such discrepancies in the phenotype might be associated with invasive techniques used to activate Cre. For instance, localized adenoviral infection of the colon by incision near the anus [6] or introducing Creexpressing virus through enema $[59,66]$, allowing these animals to survive for the long-term. Therefore, localized activation of Cre in AKMC mice will shed light on the importance of Muc4 in CRC progression and metastasis potential as these mice will survive for the long-term.

In conclusion, our study suggests that Muc4 has a protective role in CRC progression in an Apc mutant GEM mice model. Muc4 maintains the intestinal homeostasis by upregulation of Muc2 and Fam3D (guardians of the gut) and downregulation of cancerpromoting mucin (Muc13). Additionally, presence of Muc4 prevents the invasion of microbiota and reduction of proinflammatory cytokines and decrease in epithelial cell proliferation by inhibiting $\beta$-catenin, c-Myc and CD44 expression. Additional studies are needed to understand the role of Muc4 in conditional $\mathrm{KO}$ mouse models and various sub-types of CRC.

\section{MATERIALS AND METHODS}

\section{Animals and handling}

All the animals used in the present study were maintained in accordance with guidelines and protocols approved by the Institutional Animal Care and Use Committees (IACUC) of the University of Nebraska Medical Center, Omaha, NE, USA. Apc conditional knockout (Apc CKO, B6.Cg-Apctm2Rak/Nci) and Cdx2P-CreER ${ }^{\mathrm{T} 2}$ (Stock No: 022390) mice were obtained from the Mouse Model of Human Cancers Consortium (NCI-Frederick, MD, USA) and Jackson Laboratory (Bar Harbor, ME, USA), respectively. Muc4 knockout $\left(\mathrm{Muc}^{-/-}\right)$mice generated inhouse has been previously described [24]. To generate CRC mice model with or without $M u c 4^{-/}$, first we crossed mice carrying loxP-flanked Apc alleles $\left(A p c^{f l o x f f l o x}\right)$ with $M u c 4^{-/-}$to get AM mice. Second, F1 generation of AM animals were then crossed with $\mathrm{Cdx} 2 \mathrm{P}-\mathrm{CreER}^{\mathrm{T} 2}$ mice to generate $\mathrm{AMC}$ and its compound littermate's AC animals. After confirming the genotype for all the mice, colon-specific activation of Cre recombinase was carried out by administering tamoxifen (Sigma-Aldrich, St Louis, MO, USA) via intraperitoneal injection $(75 \mathrm{mg} / \mathrm{kg}$ body weight) for three consecutive days [29]. All mice (both male and female) used in the present study kept under a $12 \mathrm{~h}$ light/dark cycle, and fed a standard chow diet, and water ad libitum. The mice were euthanized by $\mathrm{CO} 2$ asphyxiation followed by cervical dislocation when they have blood in the stools, hunched appearance, and rectal prolapse.

The primers used for genotyping were as follows: ApcFP 5'-GAGAAACCCTGTCTCGAAAAAA-3', ApcRP 5'AGTGCTGTTTCTATGAGTCAA C-3' (Wild type $=320$ bp, Loxp=430 bp); Muc4FP 5'-GCCTTCTATGAAAG GTTGGGCTTCG-3', Muc4RP 5'-TCCCTTCCGGTG AAGCCTCT-3' (Wild type=331 bp, Mutant=1319 bp); Cdx-creFP 5'-CATGGTGAGGTCTGCTGATG-3', CdxcreRP 5'-CATGTCCATCAGGTTCTTGC-3' (transgene $\sim 200 \mathrm{bp}$ ).

\section{Antibodies and other reagents}

Rabbit anti-mouse mucin 2 (MUC2) antibody (H-300), mouse anti-F4/80 (sc-20047), and mouse anti-CD3 (sc377009) were obtained from Santa Cruz (Dalla, TX, USA). MUC4 (8G7) in-house generated antibody. MUC5AC antibody (CLH2, MAB2011) from Millipore. Human anti- $\beta$-catenin (C2206) and $\beta$-actin (A1978) from Sigma-Aldrich (St. Louis, MO, USA). The goat anti-mouse FAM3D antibody (AF3021) was purchased from R\&D Systems (Minneapolis, MN, USA). Nonphospho (Active) $\beta$-catenin (D2U8Y), $\beta$-catenin (D10A8), SP1 (5931), Cyclin-D1 (92G2) and c-Myc (D3N8F) obtained from Cell Signaling Technology (Danvers, MA, USA). Rabbit anti-Ki-67 (ab15580), MUC1 (ab70475) and MUC13 (ab65109) from Abcam (Cambridge, MA, USA). 4',6-diamidino-2-phenylindole (DAPI Fluoromount-G®) from Southern Biotech (Birmingham, AL, USA). was obtained from SigmaAldrich (St. Louis, MO, USA).

\section{Cell lines and culture conditions}

HCT-8, LS180, SW480 and HCT-15 cell lines were obtained from American Type Culture Collection and cultured in DMEM supplemented with $10 \%$ fetal bovine serum (FBS) and antibiotics $(100 \mathrm{U} / \mathrm{ml}$ penicillin and 
$0.1 \mathrm{mg} / \mathrm{ml}$ streptomycin) at $37^{\circ} \mathrm{C}$ with $5 \% \mathrm{CO} 2$ in a humidified atmosphere.

\section{MUC4 silencing by shRNA transfection}

The stable knockdown (KD) of MUC4 was done in the LS-180 CRC cell line by a small hairpin RNA construct (pSUPER-Retro-shMUC4). The transfection of both scrambled and MUC4-KD constructs was followed as mentioned previously $[43,50]$.

\section{Tissue processing and histological analysis of mucins}

Colon tissue was harvested for $\mathrm{AC}$ and $\mathrm{AMC}$ mice between 25-35 and 5-25 days, respectively, after tamoxifen induction. The colon was open longitudinally, and fecal material was gently removed. After washing with phosphate-buffered saline (PBS), a Swiss roll of the colon was made. For histology, tissues were fixed with $10 \%$ neutral buffered formalin prior to paraffin embedding. Both $\mathrm{AC}$ and AMC colon tissues were stained with hematoxylin and eosin, and pictures were taken with Leica ICC50 E microscope (Buffalo Grove, IL). Histological examination of grade of dysplasia was determined by the pathologist. To stain mucins, deparaffinized mouse colon tissues were immersed in Alcian blue followed by Periodic acid-Schiff (PAS) staining.

\section{In situ hybridization}

Single-color mouse-specific 20-paired double-Z oligonucleotide probes were used for in situ hybridizations of MUC4 (NM_080457.3, target region 7065 - 7996) (Advanced Cell Diagnostics, Newark, CA, USA). Briefly, tissue sections were baked for $1 \mathrm{hr}$ at $60^{\circ} \mathrm{C}$ for de-paraffinization, followed by protease treatment for $30 \mathrm{~min}$ at $40^{\circ} \mathrm{C}$. Pre-heated target probes (MUC4, positive control, and negative control, RNAscope ${ }^{\circledR} 2.5$ HD Assay- BROWN, RNAscope $\left.{ }^{\circledR}\right)$ were hybridized for $2 \mathrm{hr}$ at $40^{\circ} \mathrm{C}$, followed by a series of signal amplification and washing steps using the HybEZ Hybridization System. Hybridization signals of probes were detected by sequential chromogenic reactions using brown chromogens, and images were captured with the Leica ICC50 E microscope as described earlier [67].

\section{Immunohistochemistry}

The immunohistochemistry procedure has been described previously [43]. Both AC and AMC mice colon tissue sections were baked in an oven at $58^{\circ} \mathrm{C}$ overnight and deparaffinized in xylene and hydrated through different graded alcohols. Epitope retrieval was done by using $0.01 \mathrm{M}$ citrate buffer for $15 \mathrm{~min}$, followed by quenching endogenous peroxidase activity for $1 \mathrm{hr}$ in the dark. The sections were then blocked with $2.5 \%$ horse serum and then incubated with respective primary antibodies at $4^{\circ} \mathrm{C}$ overnight. The next day after washing, slides were probed with secondary HRP labelled universal anti-mouse/rabbit IgG for $1 \mathrm{hr}$ and then added DAB substrate kit (Vector Laboratories, Burlingame, CA, USA) according to the manufacturer. Finally, nuclei were counterstained with hematoxylin, and intensity scoring was done by a pathologist. The composite score was calculated as mentioned previously $[43,68]$.

\section{Fluorescence in situ hybridization (FISH)}

The FISH procedure was performed according to Cassmann et al., 2016 with slight modifications [69]. Briefly, tissues were dewaxed in xylene $(3 \times 10 \mathrm{~min})$ and washed in $100 \%$ alcohol (2x5 $\mathrm{min}), 95 \%$ (5 min), and $70 \%$ (5 min). After ethanol wash, slides were further rinsed with deionized water and air-dried. Tissue sections were incubated with $100 \mathrm{ng} / \mathrm{ul}$ of 5 '-Cy3 labelled universal DNA-probe mix EUB338 (5'GCTGCCTCCCGTAGGAGT-3') or with a non-specific negative probe NON338 (5'-ACTCCTACGGGAGGCA GC-3', both purchased from Eurofins MWG Operon, Louisville, KY) in a hybridization buffer $(20 \mathrm{mM}$ Tris$\mathrm{HCl}, \mathrm{pH} 7.4 ; 0.9 \mathrm{M} \mathrm{NaCl} ; 0.1 \%$ sodium dodecyl sulfate) at $37^{\circ} \mathrm{C}$ overnight. The next day, tissues were rinsed with wash buffer $(20 \mathrm{mM}$ Tris- $\mathrm{HCl}, \mathrm{pH} 7.4 ; 0.9$ $\mathrm{M} \mathrm{NaCl}$ ) at $37^{\circ} \mathrm{C}$ for $15 \mathrm{~min}$ and counterstained with anti-fade Vectashield mounting medium (Vector Laboratories, Burlingame, CA, USA) along with DAPI for Laser confocal microscopy by using LSM 510 microscope (Carl Zeiss GmbH, Germany).

\section{Real-time quantitative PCR}

Total RNA from AC and AMC animals, as well as Scr and ShMUC4 of LS-180 and HCT-8 cell lines were extracted by using RNeasy Mini Kit (Qiagen, Germantown, MD, USA) and 1 ug of total RNA was reverse transcribed to cDNA by using $5 \mathrm{x}$ iScript ${ }^{\mathrm{TM}} \mathrm{RT}$ supermix (Bio-rad, USA) according to the manufacturer's protocol. After cDNA conversion, quantitative RT-PCR was carried out on Bio-rad CFX Connect ${ }^{\mathrm{TM}}$ Real-Time system by using SYBR Green master mix. The PCR program contains $95^{\circ} \mathrm{C}$ for $5 \mathrm{~min}$; 40 cycles of $95^{\circ} \mathrm{C}$ for $30 \mathrm{sec}, 58^{\circ} \mathrm{C}$ for $30 \mathrm{sec}$, and $72^{\circ} \mathrm{C}$ for $30 \mathrm{sec}$; and $72^{\circ} \mathrm{C}$ for $5 \mathrm{~min}$. To obtain the $\Delta$ ct value, the expression of genes was normalized to GAPDH and $\beta$ actin and calculated $2^{\wedge}$ - (average $\Delta \mathrm{ct}$ ) $[70,71]$. The list of primers used in the present study are listed in Table 1.

\section{Sub-cellular fractionation}

For cytoplasmic and nuclear fractionation, the LS-180 cell line was rinsed with ice-cold PBS and incubated in 
Table 1. Real time PCR primers used in this study.

\begin{tabular}{|c|c|c|}
\hline Genes & Forward primer (5'-3') & Reverse primer (5'-3') \\
\hline \multicolumn{3}{|c|}{ Mouse primers } \\
\hline Muc13 & GGACCCAGGCAAATGACAATA & CCCTGCTTTCCTACCAACTAAC \\
\hline Muc $5 a c$ & CTGTAACACCCAGTGTCCTAAG & AGGCTGGTAGAAGTAGGTAGAA \\
\hline Muc16 & CCTCCTGAACCACAGAACATAA & CTGGATGGACAACTTTGGTAGA \\
\hline $\operatorname{Reg} 3 b$ & AATGGAGGTGGATGGGAATG & CCACAGAAAGCACGGTCTAA \\
\hline $\operatorname{Reg} 3 \gamma$ & CTTCCTGTCCTCCATGATCAAA & СCACСTCTGTTGGGTTCATAG \\
\hline Saa3 & AGCCAAAGATGGGTCCAGTT & TCAGAGTAGGCTCGCCACAT \\
\hline $\operatorname{Tnf} \alpha$ & CTACCTTGTTGCCTCCTCTTT & GAGCAGAGGTTCAGTGATGTAG \\
\hline Il6 & AGTTGCCTTCTTGGGACTGA & TCCACGATTTCCCAGAGAAC \\
\hline Cxcl2 & GACAGAAGTCATAGCCACTCTC & GCCTTGCCTTTGTTCAGTATC \\
\hline Ccl2 & TGTGCTGACCCCAAGAAGG & GGTGGTTGTGGAAAAGGTAGTG \\
\hline Cxcll & CACCCAAACCGAAGTCATAGC & GAAGCCAGCGTTCACCAGA \\
\hline Ill & GGGCTGGACTGTTTCTAATGC & CTTGTGACCCTGAGCGACC \\
\hline Ctnnbl & GACACCTCCCAAGTCCTTTATG & CTGAGCCCTAGTCATTGCATAC \\
\hline Ccndl & CAACAGGTTGTAGGGCTGGT & GGTAATGCCATCATGGTTCC \\
\hline$C d 44$ & TGGATCCGAATTAGCTGGAC & AGCTTTTTCTTCTGCCCACA \\
\hline Gapdh & ATCAAGAAGGTGGTGAAGCA & AGACAACCTGGTCCTCAGTGT \\
\hline \multicolumn{3}{|c|}{ Human primers } \\
\hline CTNNB1 & GAAACGGCTTTCAGTTGAGC & CTGGCCATATCCACCAGAGT \\
\hline$C C N D 1$ & GAGGAAGAGGAGGAGGAGGA & GAGATGGAAGGGGGAAAGAG \\
\hline$C D 44$ & AAGGTGGAGCAAACACAACC & AGCTTTTTCTTCTGCCCACA \\
\hline$A C T B$ & CACCAACTGGGACGACAT & ACA GCC TGG ATA GCA ACG \\
\hline
\end{tabular}

the presence of cytoplasmic-extraction buffer $[10 \mathrm{mM}$ HEPES (pH 7.4), $10 \mathrm{mM} \mathrm{KCl,} \mathrm{0.2 \%} \mathrm{NP-40,} 0.1 \mathrm{mM}$ EDTA, $10 \%$ glycerol, $1.5 \mathrm{mM} \mathrm{MgCl}_{2}$, supplemented with protease inhibitor cocktail, $1 \mathrm{mM}$ DTT, $1 \mathrm{mM}$ PMSF, $5 \mathrm{mM} \mathrm{Na} \mathrm{VO}_{4}$, and $5 \mathrm{mM} \mathrm{NaF}$ ] for $1 \mathrm{hr}$. The cytoplasmic fraction (supernatant) was collected after centrifugation at $16000 \mathrm{x} g$ for $20 \mathrm{~min}$. Next, pellet was washed with PBS by multiple centrifugations $\left(3 \times 5^{\prime}\right)$ at $16000 \mathrm{xg}$, after that incubated with nuclear extraction buffer [20 mM HEPES (pH 7.6), $420 \mathrm{mM} \mathrm{NaCl}, 1 \mathrm{mM}$ EDTA, 20\% glycerol, $1.5 \mathrm{mM} \mathrm{MgCl} 2,1 \mathrm{mM}$ DTT, 1 $\mathrm{mM}$ PMSF, $5 \mathrm{mM} \mathrm{Na} 3 \mathrm{VO} 4,5 \mathrm{mM} \mathrm{NaF}$ ] for $1 \mathrm{hr}$ on ice, sonicated at $60 \%$ amplitude for $10 \mathrm{~s}$ and again centrifugation at $16000 \mathrm{xg}$ for $15 \mathrm{~min}$ and the resultant supernatant was a nuclear extract.

\section{Western blot analysis}

Colon tissues from AC and AMC mice or CRC cell lines were lysed in RIPA lysis buffer along with a protease inhibitor cocktail (Roche Diagnostics, Mannheim, Germany). Equal amounts of total protein were loaded and separated by $10-12 \%$ sodium dodecyl sulfatepolyacrylamide gel electrophoresis and transferred onto polyvinylidene difluoride membranes. Due to its high molecular weight, MUC4, MUC5AC and MUC1 were resolved in 2\% SDS-agarose gel. After blotting, membranes were blocked for $1 \mathrm{hr}$ in 5\% non-fat dry milk containing phosphate-buffered saline and $0.1 \%$ Tween $20(\mathrm{v} / \mathrm{v})$ and incubated with indicated primary antibodies overnight at $4^{\circ} \mathrm{C}$, followed by incubation for $1 \mathrm{hr}$ with respective secondary antibodies and protein bands were detected with a chemiluminescence reagent (GE Healthcare Bio-Sciences, Pittsburgh, PA, USA).

\section{Statistical analysis}

All statistical analysis was performed by using Student's t-test, and the data were analyzed using GraphPad Prism Software 7.0 (San Diego, CA, USA). All the data are presented as mean \pm standard errors of the mean. $p<0.05$ was considered statistically significant.

\section{Abbreviations}

CRC: Colorectal cancer; MUC4: mucin 4; APC: adenomatous polyposis coli; GEM: genetically engineered mouse; Cdx-2: caudal type homeobox transcription factor 2; MUC2: mucin 2; DAPI: 4',6-diamidino-2-phenylindole; FBS: fetal bovine serum; KD: knockdown; PBS: phosphate buffered saline; PAS: Periodic acid-Schiff; FISH: Fluorescence in situ hybridization; HEPES: 4-(2-hydroxyethyl)-1piperazine-ethanesulfonic acid; $\mathrm{KCl}$ : potassium chloride; 
EDTA: Ethylenediaminetetraacetic acid; $\mathrm{MgCl}_{2}$ : Magnesium chloride; DTT: Dithiothreitol; PMSF: Phenylmethanesulfonyl fluoride; $\mathrm{Na}_{3} \mathrm{VO}_{4}$ : Sodium orthovanadate; NaF: Sodium fluoride: RIPA: Radioimmunoprecipitation assay buffer: TCGA: The Cancer Genome Atlas; KD: Knockdown; PCR: Polymerase Chain Reaction; AC: $\mathrm{Apc}^{--} ; \mathrm{Cdx} 2 \mathrm{P}-\mathrm{creERT}^{2}$;

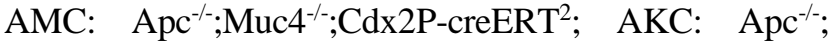
$\mathrm{Kras}^{\mathrm{G} 12 \mathrm{D} /+} ; \mathrm{Cdx} 2 \mathrm{P}-\mathrm{creERT}^{2} ; \quad$ AKMC: $\mathrm{Apc}^{-/-} ; \mathrm{Kras}^{\mathrm{G} 12 \mathrm{D} /+}$; Muc4 $^{-/-} ; \mathrm{Cdx} 2 \mathrm{P}-\mathrm{creERT}^{2}$.

\section{AUTHOR CONTRIBUTIONS}

R.P., S.K.B. designed the study. R.P., P.P., S.C. and J.A.S. contributed to in vitro as well as in vivo experiments. J.L.C., S.R., S.K., H.K.R., M.B. and S.K.B. discussed the results and reviewed the manuscript. S.R. and S.K.B. supervised the study. All the authors reviewed and approved the final manuscript.

\section{ACKNOWLEDGMENTS}

We thank Dr. Raghupathy Vengoji for assisting in animal handling.

\section{CONFLICTS OF INTEREST}

SKB is one of the co-founders of Sanguine Diagnostics and Therapeutics, Inc. The other authors declare no conflicts of interest.

\section{FUNDING}

This study was funded in part by VA Merit Review grant number 1 I01 BX004494-01 (MB and SKB).

\section{REFERENCES}

1. Fearon ER, Vogelstein B. A genetic model for colorectal tumorigenesis. Cell. 1990; 61:759-67.

https://doi.org/10.1016/0092-8674(90)90186-I

PMID:2188735

2. Kuipers EJ, Grady WM, Lieberman D, Seufferlein T, Sung JJ, Boelens PG, van de Velde CJ, Watanabe T. Colorectal cancer. Nat Rev Dis Primers. 2015; 1:15065.

https://doi.org/10.1038/nrdp.2015.65

PMID:27189416

3. Pothuraju R, Krishn SR, Gautam SK, Pai P, Ganguly K, Chaudhary S, Rachagani S, Kaur S, Batra SK. Mechanistic and Functional Shades of Mucins and Associated Glycans in Colon Cancer. Cancers (Basel). 2020; 12:649.

https://doi.org/10.3390/cancers12030649

PMID:32168759
4. Siegel RL, Miller KD, Fuchs HE, Jemal A. Cancer Statistics, 2021. CA Cancer J Clin. 2021; 71:7-33. https://doi.org/10.3322/caac.21654 PMID:33433946

5. Byun AJ, Hung KE, Fleet JC, Bronson RT, Mason JB, Garcia PE, Crott JW. Colon-specific tumorigenesis in mice driven by Cre-mediated inactivation of Apc and activation of mutant Kras. Cancer Lett. 2014; 347:191-5. https://doi.org/10.1016/i.canlet.2014.03.004 PMID:24632531

6. Hung KE, Maricevich MA, Richard LG, Chen WY, Richardson MP, Kunin A, Bronson RT, Mahmood U, Kucherlapati R. Development of a mouse model for sporadic and metastatic colon tumors and its use in assessing drug treatment. Proc Natl Acad Sci USA. 2010; 107:1565-70.

https://doi.org/10.1073/pnas.0908682107 PMID:20080688

7. Xue Y, Johnson R, Desmet M, Snyder PW, Fleet JC. Generation of a transgenic mouse for colorectal cancer research with intestinal cre expression limited to the large intestine. Mol Cancer Res. 2010; 8:1095-104. https://doi.org/10.1158/1541-7786.MCR-10-0195 PMID:20663863

8. Heijstek MW, Kranenburg O, Borel Rinkes IH. Mouse models of colorectal cancer and liver metastases. Dig Surg. 2005; 22:16-25. https://doi.org/10.1159/000085342 PMID:15838167

9. Peterson LW, Artis D. Intestinal epithelial cells: regulators of barrier function and immune homeostasis. Nat Rev Immunol. 2014; 14:141-53. https://doi.org/10.1038/nri3608 PMID:24566914

10. Vaishnava S, Yamamoto M, Severson KM, Ruhn KA, Yu $\mathrm{X}$, Koren O, Ley R, Wakeland EK, Hooper LV. The antibacterial lectin Reglllgamma promotes the spatial segregation of microbiota and host in the intestine. Science. 2011; 334:255-8. https://doi.org/10.1126/science.1209791 PMID:21998396

11. Kufe DW. Mucins in cancer: function, prognosis and therapy. Nat Rev Cancer. 2009; 9:874-85. https://doi.org/10.1038/nrc2761 PMID:19935676

12. Rachagani S, Torres MP, Moniaux N, Batra SK. Current status of mucins in the diagnosis and therapy of cancer. Biofactors. 2009; 35:509-27.

https://doi.org/10.1002/biof.64 PMID:19904814

13. Mimeault M, Brand RE, Sasson AA, Batra SK. Recent advances on the molecular mechanisms involved in pancreatic cancer progression and therapies. Pancreas. 2005; 31:301-16. 
https://doi.org/10.1097/01.mpa.0000175893.04660.1b PMID:16258363

14. Mukhopadhyay P, Chakraborty S, Ponnusamy MP, Lakshmanan I, Jain M, Batra SK. Mucins in the pathogenesis of breast cancer: implications in diagnosis, prognosis and therapy. Biochim Biophys Acta. 2011; 1815:224-40.

https://doi.org/10.1016/j.bbcan.2011.01.001

PMID:21277939

15. Singh AP, Moniaux N, Chauhan SC, Meza JL, Batra SK. Inhibition of MUC4 expression suppresses pancreatic tumor cell growth and metastasis. Cancer Res. 2004; 64:622-30.

https://doi.org/10.1158/0008-5472.CAN-03-2636

PMID:14744777

16. Torres MP, Ponnusamy MP, Lakshmanan I, Batra SK. Immunopathogenesis of ovarian cancer. Minerva Med. 2009; 100:385-400.

PMID:19910891

17. Krishn $S R$, Kaur $S$, Smith $L M$, Johansson $S L$, Jain $M$, Patel A, Gautam SK, Hollingsworth MA, Mandel U, Clausen H, Lo WC, Fan WT, Manne U, Batra SK. Mucins and associated glycan signatures in colon adenomacarcinoma sequence: prospective pathological implication(s) for early diagnosis of colon cancer. Cancer Lett. 2016; 374:304-14.

https://doi.org/10.1016/j.canlet.2016.02.016

PMID:26898938

18. Ogata S, Uehara H, Chen A, Itzkowitz SH. Mucin gene expression in colonic tissues and cell lines. Cancer Res. 1992; 52:5971-8.

PMID: 1394223

19. Biemer-Hüttmann $A E$, Walsh $M D$, McGuckin $M A$, Ajioka $Y$, Watanabe $H$, Leggett BA, Jass JR. Immunohistochemical staining patterns of MUC1, MUC2, MUC4, and MUC5AC mucins in hyperplastic polyps, serrated adenomas, and traditional adenomas of the colorectum. J Histochem Cytochem. 1999; 47:1039-48.

https://doi.org/10.1177/002215549904700808 PMID:10424888

20. David L, Silva F, Seruca R, Pinto M, Reis C, SobrinhoSimões M. Correspondence re: A. E. Biemer-Huttmann et al., Mucin core protein expression in colorectal cancers with high levels of microsatellite instability indicates a novel pathway of morphogenesis. Clin. Cancer Res., 6: 1909-1916, 2000. Clin Cancer Res. 2000; 6:4461-2.

PMID:11106267

21. Biemer-Hüttmann $A E$, Walsh $M D$, McGuckin $M A$, Simms LA, Young J, Leggett BA, Jass JR. Mucin core protein expression in colorectal cancers with high levels of microsatellite instability indicates a novel pathway of morphogenesis. Clin Cancer Res. 2000; 6:1909-16.

PMID:10815915

22. Huang $X$, Wang $X$, Lu SM, Chen $C$, Wang J, Zheng YY, Ren $\mathrm{BH}, \mathrm{Xu}$ L. Clinicopathological and prognostic significance of MUC4 expression in cancers: evidence from meta-analysis. Int J Clin Exp Med. 2015; 8:10274-83.

PMID:26379819

23. Shanmugam C, Jhala NC, Katkoori VR, Wan W, Meleth $S$, Grizzle WE, Manne U. Prognostic value of mucin 4 expression in colorectal adenocarcinomas. Cancer. 2010; 116:3577-86. https://doi.org/10.1002/cncr.25095 PMID:20564074

24. Das $S$, Rachagani S, Sheinin $Y$, Smith LM, Gurumurthy $\mathrm{CB}$, Roy HK, Batra SK. Mice deficient in Muc4 are resistant to experimental colitis and colitis-associated colorectal cancer. Oncogene. 2016; 35:2645-54.

https://doi.org/10.1038/onc.2015.327 PMID:26364605

25. Crocker PR. Siglecs: sialic-acid-binding immunoglobulin-like lectins in cell-cell interactions and signalling. Curr Opin Struct Biol. 2002; 12:609-15. https://doi.org/10.1016/S0959-440X(02)00375-5 PMID:12464312

26. Liang $\mathrm{W}$, Peng $\mathrm{X}$, Li $\mathrm{Q}$, Wang $\mathrm{P}$, Lv $\mathrm{P}$, Song $\mathrm{Q}$, She $\mathrm{S}$, Huang S, Chen K, Gong W, Yuan W, Thovarai V, Yoshimura $\mathrm{T}$, et al. FAM3D is essential for colon homeostasis and host defense against inflammation associated carcinogenesis. Nat Commun. 2020; 11:5912.

https://doi.org/10.1038/s41467-020-19691-z PMID:33219235

27. Johansson ME, Phillipson $M$, Petersson J, Velcich $A$, Holm L, Hansson GC. The inner of the two Muc2 mucin-dependent mucus layers in colon is devoid of bacteria. Proc Natl Acad Sci USA. 2008; 105:15064-9. https://doi.org/10.1073/pnas.0803124105 PMID:18806221

28. White BD, Chien AJ, Dawson DW. Dysregulation of Wnt/ $\beta$-catenin signaling in gastrointestinal cancers. Gastroenterology. 2012; 142:219-32. https://doi.org/10.1053/i.gastro.2011.12.001 PMID:22155636

29. Mallya K, Haridas D, Seshacharyulu P, Pothuraju R, Junker WM, Krishn SR, Muniyan S, Vengoji R, Batra SK, Rachagani S. Acinar transformed ductal cells exhibit differential mucin expression in a tamoxifen-induced pancreatic ductal adenocarcinoma mouse model. Biol Open. 2020; 9: bio052878.

https://doi.org/10.1242/bio.052878 PMID: $\underline{32709695}$ 
30. Tamura Y, Higashi M, Kitamoto S, Yokoyama S, Osako M, Horinouchi M, Shimizu T, Tabata M, Batra SK, Goto M, Yonezawa S. MUC4 and MUC1 expression in adenocarcinoma of the stomach correlates with vessel invasion and lymph node metastasis: an immunohistochemical study of early gastric cancer. PLoS One. 2012; 7:e49251.

https://doi.org/10.1371/journal.pone.0049251 PMID:23152882

31. Saitou M, Goto M, Horinouchi M, Tamada S, Nagata K, Hamada T, Osako M, Takao S, Batra SK, Aikou T, Imai K, Yonezawa S. MUC4 expression is a novel prognostic factor in patients with invasive ductal carcinoma of the pancreas. J Clin Pathol. 2005; 58:845-52.

https://doi.org/10.1136/jcp.2004.023572

PMID: 16049287

32. Rachagani S, Macha MA, Ponnusamy MP, Haridas D, Kaur S, Jain M, Batra SK. MUC4 potentiates invasion and metastasis of pancreatic cancer cells through stabilization of fibroblast growth factor receptor 1 . Carcinogenesis. 2012; 33:1953-64.

https://doi.org/10.1093/carcin/bgs225

PMID:22791819

33. Lakshmanan I, Seshacharyulu P, Haridas D, Rachagani S, Gupta S, Joshi S, Guda C, Yan Y, Jain M, Ganti AK, Ponnusamy MP, Batra SK. Novel HER3/MUC4 oncogenic signaling aggravates the tumorigenic phenotypes of pancreatic cancer cells. Oncotarget. 2015; 6:21085-99.

https://doi.org/10.18632/oncotarget.3912

PMID:26035354

34. Majhi PD, Lakshmanan I, Ponnusamy MP, Jain M, Das $S$, Kaur S, Shimizu ST, West WW, Johansson SL, Smith LM, Yu F, Rolle CE, Sharma P, et al. Pathobiological implications of MUC4 in non-small-cell lung cancer. J Thorac Oncol. 2013; 8:398-407.

https://doi.org/10.1097/JTO.0b013e3182829e06 PMID:23370366

35. Kamphuis JB, Mercier-Bonin $M$, Eutamène $H$, Theodorou V. Mucus organisation is shaped by colonic content; a new view. Sci Rep. 2017; 7:8527.

https://doi.org/10.1038/s41598-017-08938-3 PMID:28819121

36. Atuma C, Strugala V, Allen A, Holm L. The adherent gastrointestinal mucus gel layer: thickness and physical state in vivo. Am J Physiol Gastrointest Liver Physiol. 2001; 280:G922-9.

https://doi.org/10.1152/ajpgi.2001.280.5.G922 PMID:11292601

37. Swidsinski A, Weber J, Loening-Baucke V, Hale LP, Lochs H. Spatial organization and composition of the mucosal flora in patients with inflammatory bowel disease. J Clin Microbiol. 2005; 43:3380-9.
https://doi.org/10.1128/JCM.43.7.3380-3389.2005 PMID:16000463

38. Bergstrom K, Fu J, Johansson ME, Liu X, Gao N, Wu Q, Song J, McDaniel JM, McGee S, Chen W, Braun J, Hansson GC, Xia L. Core 1- and 3-derived O-glycans collectively maintain the colonic mucus barrier and protect against spontaneous colitis in mice. Mucosal Immunol. 2017; 10:91-103. https://doi.org/10.1038/mi.2016.45 PMID:27143302

39. Corfield AP, Wagner SA, Clamp JR, Kriaris MS, Hoskins LC. Mucin degradation in the human colon: production of sialidase, sialate O-acetylesterase, $\mathrm{N}$-acetylneuraminate lyase, arylesterase, and glycosulfatase activities by strains of fecal bacteria. Infect Immun. 1992; 60:3971-8.

https://doi.org/10.1128/iai.60.10.3971-3978.1992 PMID:1398908

40. Xu J, Gordon Jl. Honor thy symbionts. Proc Natl Acad Sci USA. 2003; 100:10452-9.

https://doi.org/10.1073/pnas.1734063100 PMID:12923294

41. Velcich A, Yang W, Heyer J, Fragale A, Nicholas C, Viani S, Kucherlapati R, Lipkin M, Yang K, Augenlicht L. Colorectal cancer in mice genetically deficient in the mucin Muc2. Science. 2002; 295:1726-9.

https://doi.org/10.1126/science.1069094 PMID:11872843

42. Liu Z, Gu Y, Li X, Zhou L, Cheng $X$, Jiang $H$, Huang $Y$, Zhang $Y, X u$ T, Yang W, Huang Q. Mucin 16 Promotes Colorectal Cancer Development and Progression Through Activation of Janus Kinase 2. Dig Dis Sci. 2021. https://doi.org/10.1007/s10620-021-07004-3 PMID:33982216

43. Pothuraju R, Rachagani S, Krishn SR, Chaudhary S, Nimmakayala RK, Siddiqui JA, Ganguly K, Lakshmanan I, Cox JL, Mallya K, Kaur S, Batra SK. Molecular implications of MUC5AC-CD44 axis in colorectal cancer progression and chemoresistance. Mol Cancer. 2020; 19:37.

https://doi.org/10.1186/s12943-020-01156-y PMID:32098629

44. Sheng $Y H$, Wong $K Y$, Seim I, Wang R, He $Y$, Wu A, Patrick M, Lourie R, Schreiber V, Giri R, Ng CP, Popat A, Hooper J, et al. MUC13 promotes the development of colitis-associated colorectal tumors via $\beta$-catenin activity. Oncogene. 2019; 38:7294-310. https://doi.org/10.1038/s41388-019-0951-y PMID:31427737

45. Gavert N, Ben-Ze'ev A. beta-Catenin signaling in biological control and cancer. J Cell Biochem. 2007; 102:820-8. https://doi.org/10.1002/jcb.21505 PMID:17854061 
46. Reya T, Clevers H. Wnt signalling in stem cells and cancer. Nature. 2005; 434:843-50. https://doi.org/10.1038/nature03319 PMID:15829953

47. Tenbaum SP, Ordóñez-Morán P, Puig I, Chicote I, Arqués $\mathrm{O}$, Landolfi S, Fernández $Y$, Herance JR, Gispert JD, Mendizabal L, Aguilar S, Ramón y Cajal S, Schwartz $S \mathrm{Jr}$, et al. $\beta$-catenin confers resistance to PI3K and AKT inhibitors and subverts FOXO3a to promote metastasis in colon cancer. Nat Med. 2012; 18:892-901. https://doi.org/10.1038/nm.2772 PMID:22610277

48. Korinek V, Barker N, Morin PJ, van Wichen D, de Weger $\mathrm{R}$, Kinzler KW, Vogelstein B, Clevers H. Constitutive transcriptional activation by a beta-catenin-Tcf complex in APC-/- colon carcinoma. Science. 1997; 275:1784-7.

https://doi.org/10.1126/science.275.5307.1784 PMID: $\underline{9065401}$

49. Taketo MM, Edelmann W. Mouse models of colon cancer. Gastroenterology. 2009; 136:780-98.

https://doi.org/10.1053/i.gastro.2008.12.049 PMID:19263594

50. Pai $P$, Rachagani S, Dhawan $P$, Sheinin YM, Macha MA, Qazi AK, Chugh S, Ponnusamy MP, Mallya K, Pothuraju $R$, Batra SK. MUC4 is negatively regulated through the Wnt/ $\beta$-catenin pathway via the Notch effector Hath1 in colorectal cancer. Genes Cancer. 2016; 7:154-68. https://doi.org/10.18632/genesandcancer.108 PMID:27551331

51. Pai $P$, Rachagani S, Lakshmanan I, Macha MA, Sheinin Y, Smith LM, Ponnusamy MP, Batra SK. The canonical Wnt pathway regulates the metastasis-promoting mucin MUC4 in pancreatic ductal adenocarcinoma. Mol Oncol. 2016; 10:224-39.

https://doi.org/10.1016/i.molonc.2015.10.005 PMID:26526617

52. Bürtin F, Mullins CS, Linnebacher M. Mouse models of colorectal cancer: Past, present and future perspectives. World J Gastroenterol. 2020; 26: 1394-426.

https://doi.org/10.3748/wig.v26.i13.1394

PMID:32308343

53. Evans JP, Sutton PA, Winiarski BK, Fenwick SW, Malik $\mathrm{HZ}$, Vimalachandran D, Tweedle EM, Costello E, Palmer DH, Park BK, Kitteringham NR. From mice to men: murine models of colorectal cancer for use in translational research. Crit Rev Oncol Hematol. 2016; 98:94-105.

https://doi.org/10.1016/i.critrevonc.2015.10.009 PMID:26558688

54. Mclntyre RE, Buczacki SJ, Arends MJ, Adams DJ. Mouse models of colorectal cancer as preclinical models. BioEssays. 2015; 37:909-20. https://doi.org/10.1002/bies.201500032 PMID:26115037

55. Taketo MM. Mouse models of gastrointestinal tumors. Cancer Sci. 2006; 97:355-61. https://doi.org/10.1111/i.1349-7006.2006.00190.x PMID:16630131

56. Moser AR, Pitot HC, Dove WF. A dominant mutation that predisposes to multiple intestinal neoplasia in the mouse. Science. 1990; 247:322-4. https://doi.org/10.1126/science.2296722 PMID:2296722

57. Su LK, Kinzler KW, Vogelstein B, Preisinger AC, Moser AR, Luongo C, Gould KA, Dove WF. Multiple intestinal neoplasia caused by a mutation in the murine homolog of the APC gene. Science. 1992; 256:668-70.

https://doi.org/10.1126/science.1350108 PMID:1350108

58. Hinoi T, Akyol A, Theisen BK, Ferguson DO, Greenson JK, Williams BO, Cho KR, Fearon ER. Mouse model of colonic adenoma-carcinoma progression based on somatic Apc inactivation. Cancer Res. 2007; 67:9721-30.

https://doi.org/10.1158/0008-5472.CAN-07-2735 PMID:17942902

59. Shibata $H$, Toyama $K$, Shioya $H$, Ito $M$, Hirota $M$, Hasegawa S, Matsumoto H, Takano H, Akiyama T, Toyoshima K, Kanamaru R, Kanegae Y, Saito I, et al. Rapid colorectal adenoma formation initiated by conditional targeting of the Apc gene. Science. 1997; 278:120-3. https://doi.org/10.1126/science.278.5335.120 PMID:9311916

60. Shoemaker AR, Luongo C, Moser AR, Marton L, Dove WF. Somatic mutational mechanisms involved in intestinal tumor formation in Min mice. Cancer Res. 1997; 57:1999-2006. PMID:9157997

61. Kinzler KW, Vogelstein B. Lessons from hereditary colorectal cancer. Cell. 1996; 87:159-70. https://doi.org/10.1016/S0092-8674(00)81333-1 PMID:8861899

62. Davies EJ, Marsh Durban V, Meniel V, Williams GT, Clarke AR. PTEN loss and KRAS activation leads to the formation of serrated adenomas and metastatic carcinoma in the mouse intestine. J Pathol. 2014; 233:27-38.

https://doi.org/10.1002/path.4312

PMID:24293351

63. Haigis KM, Kendall KR, Wang $Y$, Cheung $A$, Haigis $M C$, Glickman JN, Niwa-Kawakita M, Sweet-Cordero A, Sebolt-Leopold J, Shannon KM, Settleman J, Giovannini $M$, Jacks T. Differential effects of oncogenic K-Ras and 
$\mathrm{N}$-Ras on proliferation, differentiation and tumor progression in the colon. Nat Genet. 2008; 40:600-8. https://doi.org/10.1038/ng.115

PMID:18372904

64. Janssen KP, Alberici P, Fsihi H, Gaspar C, Breukel C, Franken P, Rosty C, Abal M, El Marjou F, Smits R, Louvard D, Fodde R, Robine S. APC and oncogenic KRAS are synergistic in enhancing Wnt signaling in intestinal tumor formation and progression. Gastroenterology. 2006; 131:1096-109.

https://doi.org/10.1053/i.gastro.2006.08.011

PMID:17030180

65. Sansom OJ, Meniel V, Wilkins JA, Cole AM, Oien KA, Marsh V, Jamieson TJ, Guerra C, Ashton GH, Barbacid $M$, Clarke AR. Loss of Apc allows phenotypic manifestation of the transforming properties of an endogenous K-ras oncogene in vivo. Proc Natl Acad Sci USA. 2006; 103:14122-7.

https://doi.org/10.1073/pnas.0604130103

PMID:16959882

66. Jonkers J, Berns A. Conditional mouse models of sporadic cancer. Nat Rev Cancer. 2002; 2:251-65.

https://doi.org/10.1038/nrc777

PMID:12001987

67. Siddiqui JA, Seshacharyulu $P$, Muniyan $S$, Pothuraju $R$, Khan P, Vengoji R, Chaudhary S, Maurya SK, Lele SM, Jain M, Datta K, Nasser MW, Batra SK. GDF15 promotes prostate cancer bone metastasis and colonization through osteoblastic CCL2 and RANKL activation. Bone Res. 2022; 10:6. https://doi.org/10.1038/s41413-021-00178-6

PMID:35058441

68. Chaudhary S, Pothuraju R, Rachagani S, Siddiqui JA, Atri P, Mallya K, Nasser MW, Sayed Z, Lyden ER, Smith L, Gupta SD, Ralhan R, Lakshmanan I, et al. Dual blockade of EGFR and CDK4/6 delays head and neck squamous cell carcinoma progression by inducing metabolic rewiring. Cancer Lett. 2021; 510:79-92. https://doi.org/10.1016/i.canlet.2021.04.004 PMID:33878394

69. Cassmann E, White R, Atherly T, Wang C, Sun Y, Khoda $\mathrm{S}$, Mosher $\mathrm{C}$, Ackermann $\mathrm{M}$, Jergens $\mathrm{A}$. Alterations of the Ileal and Colonic Mucosal Microbiota in Canine Chronic Enteropathies. PLoS One. 2016; 11:e0147321. https://doi.org/10.1371/journal.pone.0147321 PMID:26840462

70. Pothuraju R, Sharma RK, Chagalamarri J, Kavadi PK, Jangra $S$. Influence of milk fermented with Lactobacillus rhamnosus NCDC 17 alone and in combination with herbal ingredients on diet induced adiposity and related gene expression in C57BL/6J mice. Food Funct. 2015; 6:3576-84. https://doi.org/10.1039/C5FO00781J PMID:26327356

71. Pothuraju R, Sharma RK, Kavadi PK, Chagalamarri J, Jangra S, Bhakri G, De S. Anti-obesity effect of milk fermented by Lactobacillus plantarum NCDC 625 alone and in combination with herbs on high fat diet fed C57BL/6J mice. Benef Microbes. 2016; 7:375-85. https://doi.org/10.3920/BM2015.0083 PMID:26925603 


\section{SUPPLEMENTARY MATERIALS}

\section{Supplementary Figures}

A
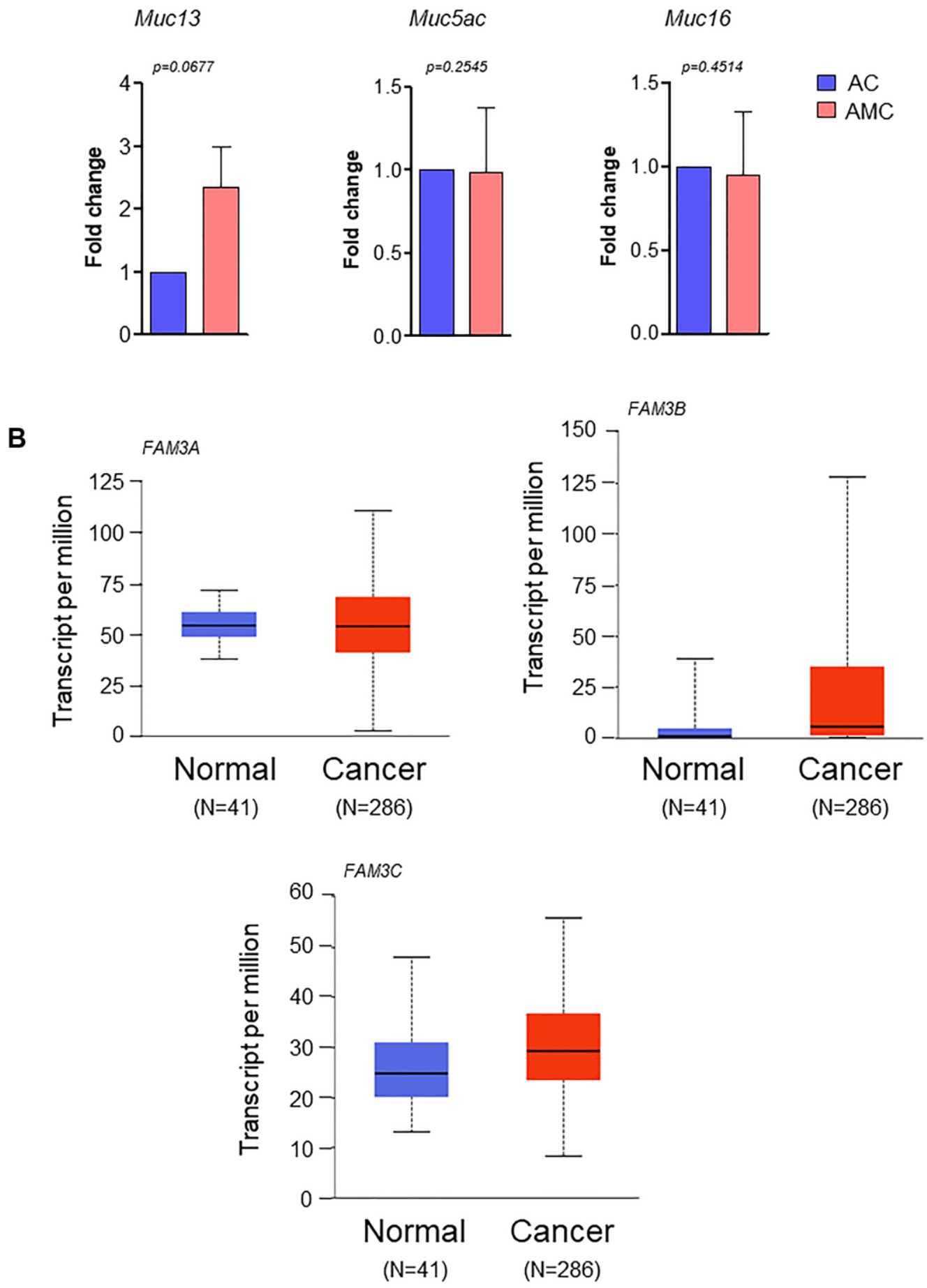

Supplementary Figure 1. The absence of Muc4 alters other mucins and FAM3 expressions. (A) mRNA expression levels of transmembrane (Muc13, Muc16) and secreted mucin (Muc5ac) in the colons of AC and AMC mice measured by real-time PCR. $n=4$ per group. (B) TCGA-COAD expression analysis of FAM family members (FAM3A, FAM3B, and FAM3C). 

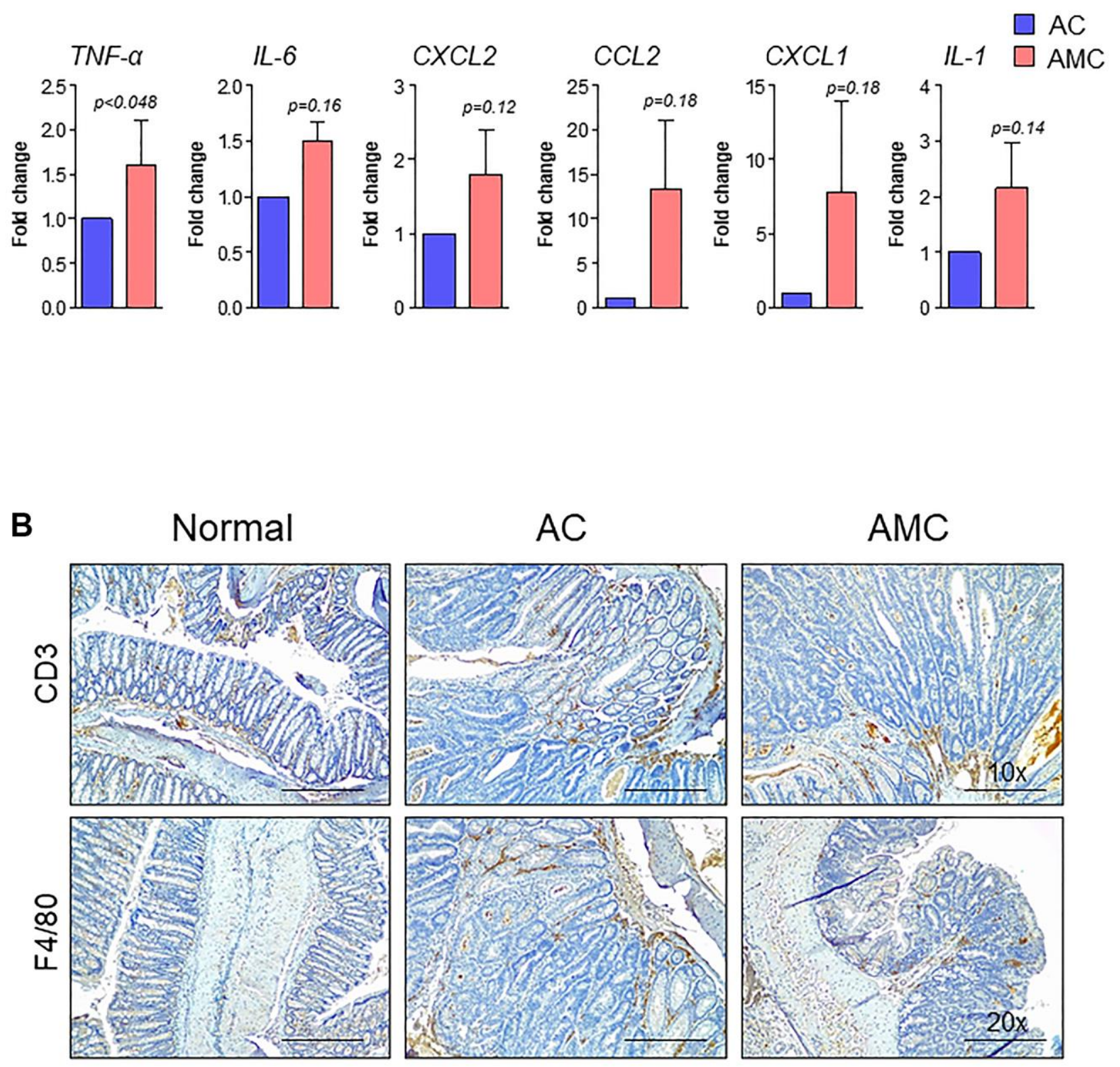

Supplementary Figure 2. Loss of Muc4 showed changes in the expression of cytokines and inflammatory markers. (A) mRNA expression levels of proinflammatory cytokines (Tnfa, IL-6, CxCl2, CCl2, CxCl1 and IL-1) in the colons of AC and AMC mice measured by realtime PCR. $n=3-4$ per group. (B) Immunohistochemical staining of immune filtration markers (CD3 ${ }^{+}$and $\left.F 4 / 80\right)$ in normal, AC, and AMC mice. $n=6(A C$ and $A M C)$ and $n=3$ for normal group. 
A $\square \mathrm{AC} \square \mathrm{AMC}$
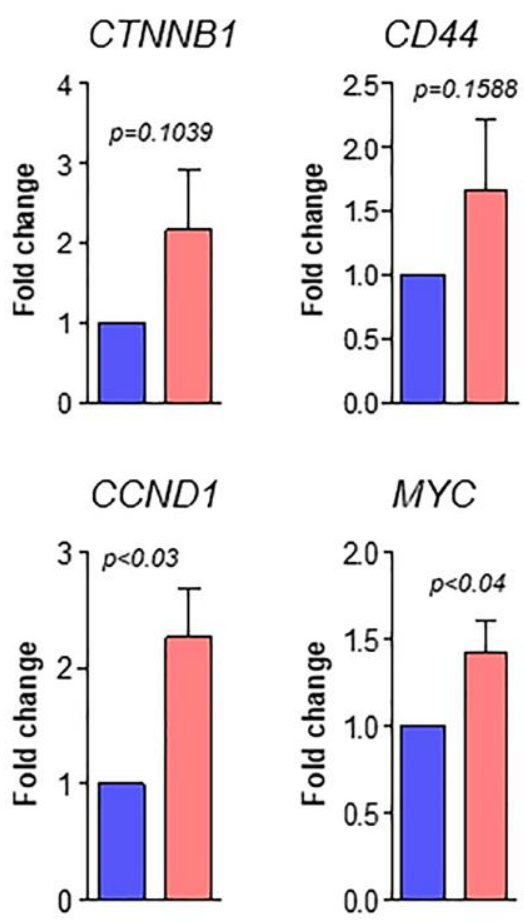

B
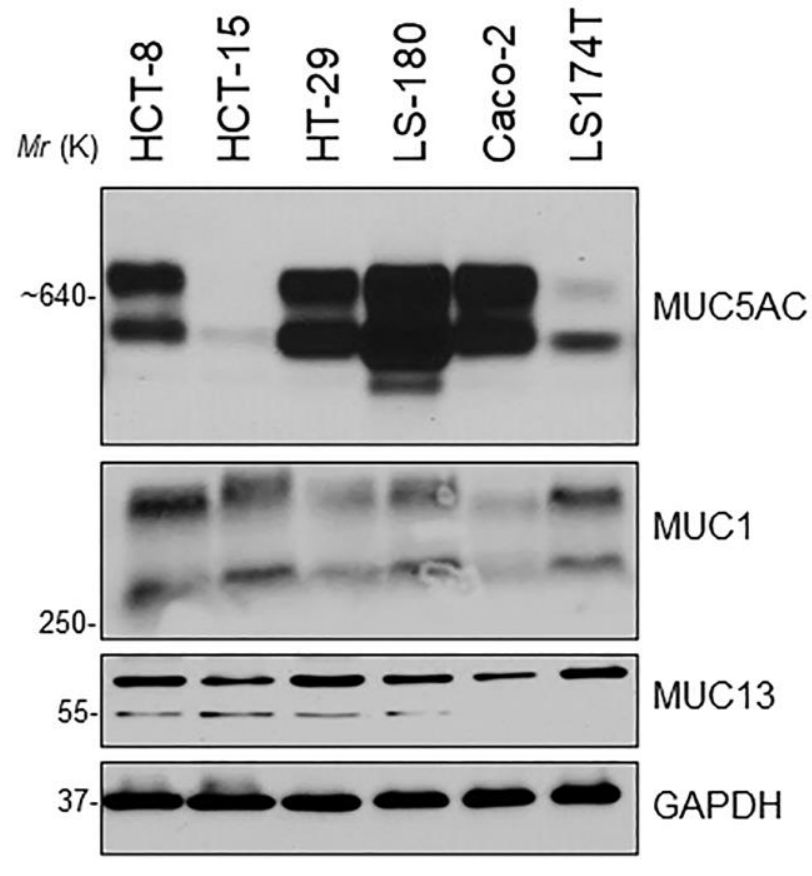

C

LS-180

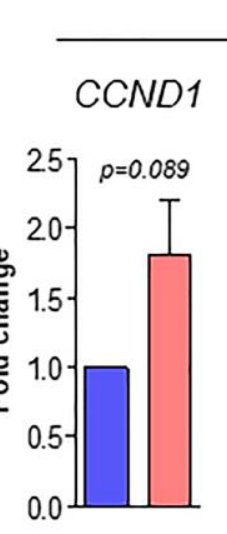

\section{CTNNB1}

CD44
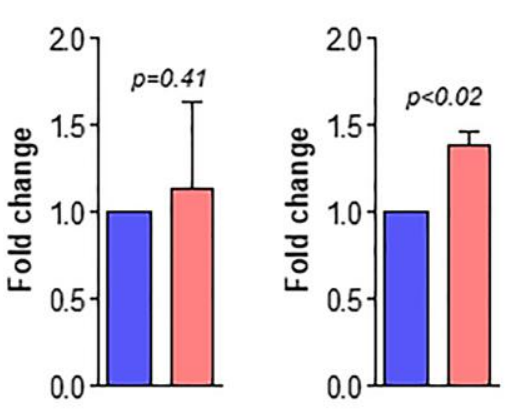

HCT-8
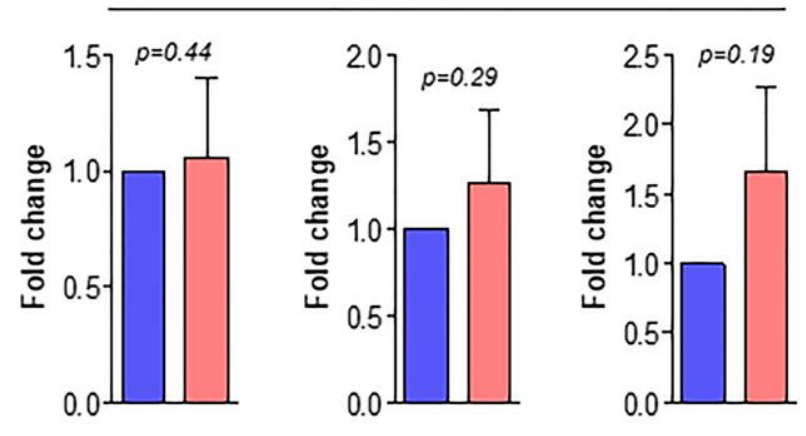

Supplementary Figure 3. The absence of Muc4 mediates upregulation of $\beta$-catenin and its target genes (A) mRNA expression levels of Ctnnb1, Cd44, Ccnd1, and Myc in the colons of AC and AMC mice measured by real-time PCR. $\mathrm{n}=4$ per group. (B) Screening different types of mucins (MUC5AC, MUC1 and MUC13) in a panel of CRC cell lines by western blot. (C) mRNA expression levels of CCND1, CTNNB1, and CD44 in Scr and MUC4-KD CRC cell lines (LS-180 and HCT-8) measured by real-time PCR. $\mathrm{n}=3$ per group. 